\title{
11. PHYSICAL PROPERTIES OF SEDIMENT RECOVERED ON DEEP SEA DRILLING PROJECT LEG 68 WITH THE HYDRAULIC PISTON CORER ${ }^{1}$
}

\author{
Larry A. Mayer, Graduate School of Oceanography, University of Rhode Island, \\ Kingston, Rhode Island
}

\section{INTRODUCTION}

In recent years studies of the physical properties of deep sea sediments have proven to be of tremendous value in aiding our understanding of the depositional processes at work in the ocean basins. In particular, Deep Sea Drilling Project cores have provided an opportunity to study variations of physical properties to great depths below the seafloor and have resulted in important contributions to our understanding of deep sea sedimentation (Keller and Bennett, 1973; Bennett and Keller, 1973; Lee, 1973; Rocker, 1974; Schlanger and Douglas, 1974; Trabant et al., 1975; Tucholke et al., 1976; Trabant, 1978; Demars et al., 1979). These studies, however, have all been hampered by the sometimes severe disturbance caused by rotary drilling and the consequent difficulty in recovering continuous sections.

On Leg 68 the newly developed Hydraulic Piston Corer (HPC) was used to recover two virtually continuous sections of late Neogene and Quaternary sediment in the Caribbean and eastern equatorial Pacific oceans. Because no rotary drilling is involved with the HPC, the recovered material is relatively undisturbed and provides an opportunity to examine the downcore variations in the physical properties of undisturbed deep sea sediment. Also, because Leg 68 sampled sections from two different oceans, it is possible to contrast the processes at work in these two different depositional environments. This chapter examines the quality of the Leg 68 samples, discusses the significance of the results, and compares and contrasts the two sites at which the HPC cores were collected.

It is important to emphasize that the primary objective of Leg 68 was to establish an extremely detailed Neogene stratigraphy for the Caribbean and the eastern equatorial Pacific. Because the sampling of physical properties was not the primary goal, the techniques employed were not always optimal. Nonetheless, every effort was made to collect samples that would be most representative of in situ conditions. The methodology used to collect the data is described in the Introduction to this volume. The raw data are plotted in Figures 1 through 16 and are also tabulated on microfiche (back pocket, this volume). In this chapter, discussions are based on a composite data set for each of the two sites.

\footnotetext{
${ }^{1}$ Prell, W. L., Gardner, J. V., et al., Init. Repts. DSDP, 68: Washington (U.S. Govt. Printing Office).
}

This set was constructed by merging all the individual core results from a single site. The merged data set was then subdivided into two-meter depth divisions and all the data points within this window summed, and the mean value determined. The mean value was assigned to the sub-bottom depth midpoint in the sampling window. The result is a smoothed data set with one point every two meters. Each data point is the mean of all the values from all the cores at a particular site that fell within a given two-meter sub-bottom depth interval. Although this method makes detailed interproperty comparisons difficult, such detailed analyses are not within the scope of this study.

It should be noted that all measurements were made in the laboratory at $1 \mathrm{~atm}$ pressure and a temperature of approximately $21^{\circ} \mathrm{C}$. All the laboratory properties (especially porosity, density, and velocity) must be corrected to in situ (in the borehole) before valid conclusions can be made concerning in situ properties. Porosity is greater in the laboratory (and density less) because of elastic rebound of samples after removal from overburden pressure in the borehole. Velocity measured in the laboratory must be corrected in several ways to approximate in situ velocities and velocity gradients. The corrections to velocity, porosity, and density are discussed by Hamilton $(1965,1976,1979)$. Because some of these corrections are based on shore laboratory measurements and studies, only the laboratory measurements are presented in this chapter.

\section{DISTURBANCE}

No report on the mass physical properties of sediments can be complete without a discussion of sample disturbance. Because it is the key influence on physical property data, it is essential to recognize the relative quality of the samples before the data can be properly evaluated. An examination of sample quality is particularly important, since the strongest argument in favor of the HPC is its ability to retrieve nearly continuous relatively undisturbed samples. Once again, the primary objective of Leg 68-detailed stratigraphy-precluded the type of sampling necessary for quantitative disturbance studies (which would have required sealing entire unsplit sections of the core). Nonetheless, it is possible to examine qualitatively several aspects of the HPC procedure and the samples recovered with it in an attempt to evaluate sample disturbance.

The major, and by far most significant, difference between standard Deep Sea Drilling Project cores and 
HPC samples lies in the lack of drill string rotation and drilling fluid pumping during HPC core collection. The disturbance to samples caused by rotary drilling has been the subject of several studies (Demars and Nacci, 1978; Demars et al., 1979; Lee, 1973; Bennett and Keller, 1973). All these authors conclude that the churning of the rotary drill bit and the excess back-pressure of drilling muds tend to homogenize and severely disturb the sediment. This becomes especially critical in the relatively unindurated upper 200 meters of the sediment column. For the most part, this type of disturbance is visually distinguishable, although it may be difficult to discern in originally homogeneous sediment. The substantial improvement resulting from use of the HPC is immediately obvious upon visual examination of the cores: sharp lithologic contacts and even millimeter-scale varves have been preserved in HPC cores (see in Prell, Gardner, et al., 1980, fig. 2 and Joides Journal, 1979). HPC samples visually resemble standard piston cores, and the disturbance associated with HPC material is probably on the order of that associated with piston cores. Thus the visual evidence suggests that HPC material is of much higher quality than standard rotary-drilled material. Though the primary cause for this improvement in sample quality is the absence of drill string rotation and drilling fluid pumping, several other factors add to the relatively undisturbed appearance of the HPC cores.

Demars et al. (1979) identified volume increase due to swelling as a secondary cause of disturbance in DSDP samples (drained unloading). They attribute this disturbance to poor sample-liner fit resulting in water or drill mud between the sample and the liner. For the most part, the HPC samples completely fill the liners, thus minimizing this factor as a disturbance-causing mechanism. This does not mean that there was no disturbance in the Leg 68 samples; at times the sediment recovered on Leg 68 was extremely disturbed, but the disturbance was caused primarily by the recoring of material that had fallen downhole ahead of the bit. Collapsed liners and piston failures were also sources of disturbance. In general, however, samples taken with the HPC are of such high quality that it is usually quite simple to distinguish disturbed from undisturbed sections and thus avoid sampling disturbed locations. Disturbed areas were avoided during physical property measurements on Leg 68 , except for several measurements made on obviously disturbed samples for comparison purposes.

Of the shipboard physical properties, shear strength (cohesion) is by far the most sensitive to sample disturbance and may provide insight into the quality of the Leg 68 HPC samples. Vane shear strength is affected both by remolding and by changes in water content. Demars et al. (1979) report that shear strengths measured on DSDP samples may be more than $75 \%$ less than in situ values. Lee (1973) attempted to correct for drilling disturbance by measuring residual stresses and concluded that in situ strengths are two to three times greater than those of DSDP samples. It is difficult to compare shear strength values at different sites because of the substantial influence of lithology on shear strength. On Leg 16, however, shear strength measurements were made on a section (Site 159, Keller and Bennett, 1973) that is somewhat similar to HPC Site 502. The shear strengths are consistently $50-100 \%$ less than those of HPC samples from equivalent depths and possibly indicate the greater disturbance caused by drilling. This is a poor comparison (there are few and some questionable measurements at Site 159), but until strengths are measured from drilled and cored samples at the same site, it is the best that can be made.

Another possible indication of sample disturbance is sediment sensitivity - that is, the ratio of undisturbed strength to remolded strength. The typical value for deep sea sediments appears to be between 3 and 4 (Noorany and Gyinski, 1970), though higher values have been reported (Keller and Bennett, 1970). Sample disturbance should lower the value of sensitivity for a given sediment type. The mean sensitivity value for Site 502 is 4.54, whereas for Site 503 it is 7.68 (see Table 1). At Site 502 , shear strengths were measured on four samples that showed visual signs of disturbance. The sensitivity of these samples was substantially lower than the mean $(0.94,2.12,2.93,4.11)$. Of particular interest is the extremely low value measured on Section 502-29-3 (0.94), judged to represent flow-in.

The needle penetrometer measurements made on Leg 68 have little value in the absolute determination of strength properties but may be of some use in indicating subtle disturbance. A consistent (and expected) trend of decreasing penetration with depth can be seen (Fig. 17), but superimposed on this trend is an imbricate structure with penetration increasing near the top of each core down to a depth of about 120 meters. As was discussed earlier, downhole contamination was not uncommon and, when it occurred, it disturbed the top part of the core. Also, the uppermost section of each core had to pass through the entire length of the liner and thus was subjected to greater disruption than any other part.

Finally, I have just begun (January 1981) a series of consolidation tests on carefully collected samples from Leg 68 . The shape of the consolidation $(e-\log p)$ curve may be a good indicator of sample disturbance. Although these tests have only just begun, initial indications are that the samples appear relatively undisturbed, much like standard piston cores (A. Silva, personal communication). The results of these tests will be presented in a future report.

\section{SHEAR STRENGTH}

Of all the physical properties measured on Leg 68, the shear strength results present the most dramatic and intriguing contrasts between Sites 502 and 503. The shear strength versus depth curve for Site 502 (Fig. 18) is fairly typical of what would be expected for deep sea sediment in that it shows an increase in strength with depth. A closer examination of the curve reveals a rapid increase in strength with depth from 0 to 20 meters, a gentle increase from 20 to 100 meters, and a very rapid increase from 100 to 200 meters. The large fluctuations of values in the deeper part of the core are probably due to measurement error caused by the extreme stiffness of the material deeper in the section. This stiffness pre- 
Table 1. Summary statistics of the physical properties of sediment from Leg 68 .

\begin{tabular}{|c|c|c|c|c|c|}
\hline & No. & Minimum & Maximum & Mean & $\begin{array}{l}\text { Standard } \\
\text { Deviation }\end{array}$ \\
\hline \multicolumn{6}{|l|}{$\begin{array}{l}\text { Saturated Bulk } \\
\text { Density (GRAPE) }\end{array}$} \\
\hline $\begin{array}{l}\text { Site } 502 \\
\text { Site } 503\end{array}$ & $\begin{array}{l}3407 \\
1569\end{array}$ & $\begin{array}{l}1.07 \\
1.07\end{array}$ & $\begin{array}{l}1.97 \\
1.79\end{array}$ & $\begin{array}{l}1.591 \\
1.259\end{array}$ & $\begin{array}{l}0.089 \\
0.093\end{array}$ \\
\hline \multicolumn{6}{|l|}{$\begin{array}{l}\text { Acoustic Velocity } \\
\text { (through the liner) }\end{array}$} \\
\hline $\begin{array}{l}\text { Site } 502 \\
\text { Site } 503\end{array}$ & $\begin{array}{l}400 \\
184\end{array}$ & $\begin{array}{l}1.46 \\
1.48\end{array}$ & $\begin{array}{l}2.32 \\
1.57\end{array}$ & $\begin{array}{l}1.57 \\
1.52\end{array}$ & $\begin{array}{l}0.05 \\
0.01\end{array}$ \\
\hline \multicolumn{6}{|l|}{ Chunk Samples } \\
\hline $\begin{array}{l}\text { Site } 502 \\
\text { Site } 503\end{array}$ & $\begin{array}{r}336 \\
83\end{array}$ & $\begin{array}{l}1.06 \\
1.49\end{array}$ & $\begin{array}{l}2.16 \\
3.13\end{array}$ & $\begin{array}{l}1.56 \\
1.54\end{array}$ & $\begin{array}{l}0.05 \\
0.17\end{array}$ \\
\hline \multicolumn{6}{|l|}{ Needle Penetration } \\
\hline $\begin{array}{l}\text { Site } 502 \\
\text { Site } 503\end{array}$ & $\begin{array}{l}766 \\
337\end{array}$ & $\begin{array}{l}1.02 \\
1.18\end{array}$ & $\begin{array}{l}3.80 \\
4.41\end{array}$ & $\begin{array}{l}1.59 \\
1.72\end{array}$ & $\begin{array}{l}0.30 \\
0.37\end{array}$ \\
\hline \multicolumn{6}{|l|}{ Shear Strength } \\
\hline $\begin{array}{l}\text { Site } 502 \\
\text { Site } 503\end{array}$ & $\begin{array}{r}159 \\
60\end{array}$ & $\begin{array}{l}29.0 \\
45.47\end{array}$ & $\begin{array}{l}3185.4 \\
1686.4\end{array}$ & $\begin{array}{c}1067.8 \\
370.12\end{array}$ & $\begin{array}{l}837.2 \\
252.2\end{array}$ \\
\hline \multicolumn{6}{|l|}{ Remolded Strength } \\
\hline $\begin{array}{l}\text { Site } 502 \\
\text { Site } 503\end{array}$ & $\begin{array}{r}152 \\
47\end{array}$ & $\begin{array}{l}12.40 \\
13.75\end{array}$ & $\begin{array}{l}1142.0 \\
513.25\end{array}$ & $\begin{array}{c}266.5 \\
72.30\end{array}$ & $\begin{array}{r}234.84 \\
81.48\end{array}$ \\
\hline \multicolumn{6}{|l|}{ Sensitivity } \\
\hline $\begin{array}{l}\text { Site } 502 \\
\text { Site } 503\end{array}$ & $\begin{array}{r}152 \\
47\end{array}$ & $\begin{array}{l}0.94 \\
1.83\end{array}$ & $\begin{array}{l}25.39 \\
29.33\end{array}$ & $\begin{array}{l}4.54 \\
7.68\end{array}$ & $\begin{array}{l}3.14 \\
4.94\end{array}$ \\
\hline \multicolumn{6}{|l|}{ Water Content } \\
\hline $\begin{array}{l}\text { Site } 502 \\
\text { Site } 503\end{array}$ & $\begin{array}{r}292 \\
91\end{array}$ & $\begin{array}{l}32.27 \\
50.79\end{array}$ & $\begin{array}{l}53.13 \\
81.10\end{array}$ & $\begin{array}{l}42.42 \\
70.37\end{array}$ & $\begin{array}{l}3.37 \\
7.46\end{array}$ \\
\hline \multicolumn{6}{|l|}{$\begin{array}{l}\text { Saturated Bulk } \\
\text { Density }\end{array}$} \\
\hline $\begin{array}{l}\text { Site } 502 \\
\text { Site } 503\end{array}$ & $\begin{array}{r}292 \\
81\end{array}$ & $\begin{array}{l}1.42 \\
1.13\end{array}$ & $\begin{array}{l}2.01 \\
1.43\end{array}$ & $\begin{array}{l}1.58 \\
1.23\end{array}$ & $\begin{array}{l}0.06 \\
0.07\end{array}$ \\
\hline \multicolumn{6}{|l|}{ Porosity } \\
\hline $\begin{array}{l}\text { Site } 502 \\
\text { Site } 503\end{array}$ & $\begin{array}{r}292 \\
81\end{array}$ & $\begin{array}{l}56.45 \\
72.88\end{array}$ & $\begin{array}{l}84.56 \\
92.15\end{array}$ & $\begin{array}{l}66.81 \\
85.39\end{array}$ & $\begin{array}{l}3.19 \\
4.64\end{array}$ \\
\hline \multicolumn{6}{|l|}{ Grain Density } \\
\hline $\begin{array}{l}\text { Site } 502 \\
\text { Site } 503\end{array}$ & $\begin{array}{r}292 \\
81\end{array}$ & $\begin{array}{l}2.60 \\
2.24\end{array}$ & $\begin{array}{l}7.53 \\
2.86\end{array}$ & $\begin{array}{l}2.75 \\
2.60\end{array}$ & $\begin{array}{l}0.28 \\
0.11\end{array}$ \\
\hline
\end{tabular}

vented the measurement of shear strength from samples deeper than about 200 meters at Site 502. Another source of error may come from the inability of the vane shear test to yield valid measurements in sediments with abundant sand-sized material (Wilson, 1964). Johnson et al. (1977) found that sediments with greater than $36 \%$ sand produced questionable vane shear results, probably owing to grain interactions. Because the visual core descriptions of the Leg 68 cores reveal only infrequent occurrences of abundant (more than $40 \%$ ) sand-sized material (forams-and only at Site 502), determination of the significance of this factor in affecting shear vane measurements must await detailed grain-size analyses.
An increase in shear strength with depth is expected owing to the significant influence of overburden pressure on shear shrength; more intriguing, however, are the changes in the slope of the strength versus depth curve. Lee (1973) explained this pattern of strength plots by calling upon two components of strength, a frictional component (which increases linearly with normal stress) and a nonfrictional or cohesive component (independent of normal stress). The cohesive component (resulting from chemical alteration, aging, etc.) accumulates in the upper 20 meters and then is gradually destroyed over the next 80 meters because of increased overburden. Below about 100 meters, the strength is primarily frictional. Al- 
though this hypothesis may in part explain the behavior of the shear strength curve, a lithologic change at 110 meters at Site 502 provides a more substantial explanation for the rapid increase of strength beginning at that depth. Below 110 meters, there is a substantial increase in clay content and decrease in foram content (Unit C, see Site 502 site chapter and Zimmerman, this volume). The shear vane measurement is extremely sensitive to cohesion (and thus clay content), and the sharp break in the strength curve probably reflects the increased clay content and its response to increasing overburden. The increased clay content results in a more plastic sediment. More plastic sediment has been shown to have a higher strength to overburden pressure ratio (Lambe and Whitman, 1969) and to be less susceptible to disturbance (Lee, 1979). Above 110 meters (Unit B), the gradual increase in strength with depth may be attributed to the support provided by the increased foram content. In the uppermost 20 meters at Site 502, the strength increases rapidly as the material initially compacts, until the forams can begin to bear the load.

In contrast to Site 502, the shear strength values at Site 503 increase rapidly to a value of approximately 400 $\mathrm{g} / \mathrm{cm}^{2}$ at about 10 meters and then remain at that value down to 210 meters (Fig. 18). Below 210 meters, the shear strength rapidly increases to values in excess of $1700 \mathrm{~g} / \mathrm{cm}^{2}$. Two questions immediately arise: How can a sediment section fail to gain strength (indurate) for 200 meters, and, what happens at 210 meters to cause the sudden increase in strength? Once again, lithology may hold the answer. The key difference between Sites 502 and 503 is the presence of siliceous microfossils in the Site 503 section. The lack of increased strength with depth is coincident with only a very slight decrease in water content and porosity. Several authors (Hamilton, 1964; Keller and Bennett, 1973; Lee, 1973) have reported a similar lack of induration in biogenous silica-bearing sections. It appears that the mechanical interlocking framework provided by the spiny and open-structured siliceous microfossils prevents the consolidation of the section by maintaining high porosities and water contents and relatively low shear strengths. The capacity of this framework to support the section is evidenced by the open burrows that occur as deep as 64 meters sub-bottom at Site 503 (Site 503 site chapter, this volume). Also, the siliceous sediment has a very low buoyant unit weight. Overburden stress increases very slowly (Fig. $19)$, resulting in a slow increase in strength.

What then causes the sudden increase in shear strength at approximately 200 meters? Several explanations are possible. First, a significant increase in clay content occurs at approximately 226 meters sub-bottom. As mentioned earlier, the shear vane measurement is extremely sensitive to clay content (cohesion), and the strength increase beginning at 210 meters may indicate an initial increase in clay content. A second possibility is the collapse of the siliceous framework. Although this mechanism can account for an increase in shear strength, it should also be coincident with a decrease in porosity and water content. If anything, the porosity and water content at Site 503 increase below 210 meters (Figs. 20,
21 ), indicating that framework collapse is probably not the mechanism responsible for the increased strength. Finally, the strength increase may be due to a diagenetic horizon-namely, the transformation from opal A to opal CT. This material was in close proximity to basement (the deepest core at the site was probably within 10 meters of basement), and the high clay content (see Zimmerman, this volume) may represent thermal alteration. The determination of the mechanism responsible for the increased strength below 210 meters will have to await the results of the detailed consolidation, X-ray, and electron microscope studies presently underway.

Further insight into the significant differences between Sites 502 and 503 can be gained by examining the plots of the overburden pressure or effective stress versus depth at each site (Fig. 19). The effective stress (based on measured saturated bulk densities) at the bottom of Site 502 is $11.46 \mathrm{~kg} / \mathrm{cm}^{2}$ at 205 meters. The effective stress at the same depth at Site 503 is only $4.79 \mathrm{~kg} / \mathrm{cm}^{2}$, and the overburden pressure at the bottom of hole (232.9 $\mathrm{m}$ ) is only $5.47 \mathrm{~kg} / \mathrm{cm}^{2}$. Thus the Caribbean section (Site 502), with virtually no biogenous silica, exerts more than twice the pressure exerted by the equivalent thickness of biogenous silica-bearing material in the eastern equatorial Pacific (Site 503). It is particularly intriguing to compare the overburden pressure at the depths at which the shear strength begins to increase rapidly. At Site 502, the rapid increase in shear strength occurs at approximately 100 meters, where the overburden pressure is about $5.2 \mathrm{~kg} / \mathrm{cm}^{2}$. At Site 503 the "geotechnical break" in shear strength occurs at approximately 210 meters, where the overburden pressure is also about 5 $\mathrm{kg} / \mathrm{cm}^{2}$. This may be coincidental or may lend credence to the previously discussed hypothesis of Lee (1973) by representing a critical overburden threshold above which the frictional component of shear stress dominates.

\section{GRAVIMETRIC ANALYSES}

The distinct differences in shear strength curves between Sites 502 and 503 are substantiated by the results of the more basic physical property analyses: saturated bulk density, water content, porosity, and grain density, as determined by gravimetric means. The water contents and porosities at Site 503 are markedly higher than those at Site 502 (see Table 1, Figs. 20, 21), and the saturated bulk densities and grain densities are significantly lower (Figs. 22, 23). The presence of biogenous silica at Site 503 can once again be called upon to explain these differences. The open framework formed by the siliceous microfossils results in significantly higher porosities and water contents and greatly reduced saturated bulk densities. The influence of biogenous silica is further indicated by comparison of the mean grain densities of the two sites. The mean grain density for Site 502 is 2.75 $\mathrm{g} / \mathrm{cc}$, which is close to the value expected for pure carbonate or clay. The mean grain density for Site 503 is $2.60 \mathrm{~g} / \mathrm{cc}$, however, the lower value indicating the presence of biogenous silica. (The grain density of pure biogenous silica is 2.1-2.3 g/cc [Baas Becking and Moore, 1959].) The supportive nature of the silica framework becomes apparent in examining the variation with depth 
of porosity, water content, and density at Site 503 . Despite the accumulation of almost 100 meters of sediment, there appears to be no reduction in porosity or water content and no increase in saturated bulk density over this interval (Figs. 20-22). Deeper than 100 meters, there is a very slight reduction in porosity and water content with depth (increase in density), indicating a very small amount of consolidation. The porosity-depth curves for both sites are very close to the generalized examples of Hamilton (1976) for calcareous and radiolarian sediments (Fig. 21). It is particularly interesting to note that at 210 meters, where the shear strength values abruptly increase, the porosity and water content do not decrease but, rather, appear to increase. The answer may lie in the sensitivity of the shear strength measurement to small changes in clay content that have little effect on the porosity, water content, and saturated bulk density, but until detailed analyses are complete, this unexpected relationship will not be fully understood.

A similar porosity-depth interaction occurs at Site 502. The porosity and water content values at this site are much lower than those at Site 503, owing to the lack of a supportive biogenous silica framework. These values gradually decrease with depth down to about 100 meters. Below that depth, the porosity and water content values remain fairly constant until about 210 meters, where they rapidly increase (Figs. 20-22). As at Site 503 , the correlation between the shear strength and the porosity and water content curves is not as would be expected. Over the depth range in which shear strength remains constant $(10-100 \mathrm{~m})$ the porosity and water content gradually decrease (with saturated bulk density increasing). Below the "geotechnical break" at about 100 meters, the shear strength increases rapidly, whereas the porosity, water content, and density remain constant. Again, the resolution of this relationship must await more detailed analysis.

The most remarkable feature of the physical properties at Site 502 is the rapid increase in water content and porosity (and decrease in saturated bulk density) below about 200 meters depth. Amazingly, the porosity and water content values below this depth are the highest in the entire section. This most unexpected result can be explained, however, if the lithology of the core is examined: Below this level are the only siliceous microfossils at Site 502 (except in the uppermost few meters; see Site 502 site chapter, this volume). Also, at this depth the type of clay (high smectite percentage) and its crystallinity (poor) change drastically, which indicates a significant change in sediment type (see Zimmerman, this volume). Once again, the presence of siliceous microfossils has an extraordinary effect on the physical properties of the sediment. Despite the fact that there is more than $11 \mathrm{~kg} / \mathrm{cm}^{2}$ overburden pressure on the material below 200 meters (and it is more than $6.5 \mathrm{~m} . \mathrm{y}$. old), the siliceous microfossils maintain sufficient integrity to cause significantly reduced saturated bulk densities and increased porosities and water contents. A similar result was reported by Keller and Bennett (1973) at DSDP Sites 158 and 166.

Superimposed on the major changes in porosity, water content, and saturated bulk density are higher frequency variations in these properties. Understanding these high frequency variations may provide the key to extracting paleoceanographic information from the physical properties and truly understanding the causes of physical property variations. I demonstrated (Mayer, 1979) from equatorial Pacific cores that changes in key physical properties (saturated bulk density and porosity) could be directly related to changes in carbonate content, which, in turn, could be tied to glacial-interglacial cycles. Such analyses are extremely difficult on DSDP material because of the large and unequally spaced sample intervals. Because of the high quality of the HPC GRAPE data, however, it should be possible to do detailed correlations between saturated bulk density and other closely measured properties (e.g., percentage of carbonate). This work is currently underway, and preliminary results reveal that the high frequency variations in density and porosity correlate fairly well with carbonate fluctuations at Site 503, though there is very little correlation at Site 502. Although the correlation at Site 503 implies paleoclimatic forcing like that I reported in 1979, the lack of correlation at Site 502 necessitates the investigation of other possible mechanisms (e.g., grain size or crystallinity) that may account for variability in physical properties.

\section{ACOUSTIC VELOCITY}

The speed of compressional sound waves in the sediment of Leg 68 was measured by two techniques: on chunks of sediment and through the core liner (see Introduction, this volume). The results from each of these methods were quite similar (Figs. 24, 25) indicating that, for the most part, the sediment completely filled the liner, a conclusion also supported by analysis of the GRAPE data. Because of the similarity between the two velocity measurement techniques, these data sets may be combined into a single smoothed velocity versus depth plot for each site (Fig. 26).

The substantial differences between the physical properties at Sites 502 and 503 are only minimally displayed in the velocity versus depth plots. The mean velocity at Site $502(1.565 \mathrm{~km} / \mathrm{s})$ is several meters per second higher than the mean velocity at Site $503(1.53 \mathrm{~km} / \mathrm{s})$. This is a rather small difference, considering the significant differences in all other physical properties between the two sites. There is a very slight increase in velocity with depth at Site 503; at Site 502, on the other hand, the velocity actually decreases slightly down to about $100 \mathrm{me}$ ters and then very gradually increases to about 200 meters, where it decreases to the bottom of the section. The initial velocity decrease at Site 502 appears to coincide with the decrease in porosity and water content (increase in saturated bulk density) in the top 100 meters of the core. This relationship is opposite from what would be expected and will be the subject of future investigation. Superimposed upon the gross trends of the velocity curves are higher frequency fluctuations in velocity. For the most part, these fluctuations are very small-at or below the precision of the measurement. The fluctuations may be related to the high frequency variations in the other physical properties or may simply be measurement error. 
By far the most significant aspect of the velocity results is the lack of variation in laboratory velocity with depth. I found a similar result (Mayer, 1979) in equatorial Pacific piston cores, but discussion was limited to the top 10 meters because of the length of the cores. It is quite surprising to see that a lack of substantial variation in velocity with depth continues in two different sedimentary environments to depths greater than 200 meters below the seafloor. This result has particular significance for acoustic modeling of deep sea sediments. As I found for the upper 10 meters (1979), it appears that for the sediment types studied on Leg 68, modeling the acoustic impedance of the sediment section requires measuring saturated bulk density only. This is an especially exciting result, for if the HPC can recover a nearly continuous section, the GRAPE can be used to produce an almost continuous density profile. This density profile can then be converted into an impedance profile for acoustic modeling studies and for comparison with borehole instrument results.

Again, it should be emphasized that the velocitydepth relations shown are for the laboratory only. As discussed by Hamilton $(1965,1979)$, laboratory velocity values must be corrected to get in situ velocities and velocity gradients. This involves full temperature and pressure corrections from laboratory to in situ (in the borehole) and corrections for porosity due to elastic rebound. The pressure corrections involve intergranular pressure on the sediment mineral frame and hydrostatic pressure in the pore water. The temperature corrections involve the temperature gradients in the borehole as a result of heat flow through the Earth's crust.

\section{CONCLUSIONS}

The Hydraulic Piston Corer has provided nearly continuous sections of relatively undisturbed sediment from depths of more than 200 meters below the seafloor in two distinct oceanic settings. Several lines of evidence support the conclusion that this absence of disturbance is due to the lack of drill string rotation and fluid pumping in the HPC operation. First, visual examination of HPC cores reveals sharp lithologic contacts and, in some instances, millimeter-scale varves. The high quality of most samples permits the easy identification of those samples that have been disturbed owing to either recoring or core or liner failure. Secondly, shear strength values, an extremely sensitive measure of sample disturbance, appear to be significantly higher for HPC samples than for drilled samples from similar depths and of similar lithology. The sensitivity of recovered samples was typical of those measured on deep sea sediments collected with conventional piston cores and substantially greater than values determined on obviously disturbed samples of HPC material. Finally, very preliminary results of consolidation tests indicate that the samples appear relatively undisturbed. Although no sampling technique can produce a totally undisturbed sample, it does appear that the HPC, when working correctly, can produce samples that are of the quality of standard piston cores.
Sites 502 and 503 exhibit distinctly different physical property characteristics. The dominant mechanisms producing the physical property differences both downcore and between the sites appear to be lithologic variations combined with consolidation processes. At Site 502, the shear strength increases rapidly with depth coincident with an increase in clay content. A sudden increase in shear strength at the bottom of Site 503 is also coincident with an increase in clay content

By far the most significant factor controlling the physical properties of the Leg 68 sediment is the presence or absence of biogenous silica. Low grain density, open, spiny siliceous microfossils create a mechanically interlocked framework that provides a supportive mechanism for the sediment column. Thus Site 503, which is characterized by the presence of biogenous silica, maintains extremely high porosity and water contents and very low saturated bulk density and shear strength for more than 200 meters of accumulation. On the other hand, Site 502, with virtually no biogenous silica, exhibits the decreasing porosity and water contents and increasing saturated bulk densities and shear strength normally associated with a compacting section. Most intriguing is the sudden increase in porosity and water content (decrease in saturated bulk density) to the highest values in the entire section, found in the bottommost samples at Site 502. This dramatic and unexpected change in physical properties coincides with the only occurrence of biogenous silica at Site 502 (except for the top few meters) and represents a major change in sediment type. At slightly below 200 meters core depth at Site 502 , the sediment changes from a foram-bearing nannofossil marl/clay with no siliceous microfossils, low smectite percentage, and high crystallinity to a calcareous clay with common siliceous microfossils, high smectite percentage, and poor crystallinity. The sediment below about 200 meters is very similar in physical and mineralogical properties to that recovered at Site 503. Thus there appears to be a rather rapid change between " $\mathrm{Pa}$ cific-type" sediment below about 200 meters to "Atlantic-type" material above that level. The implications of this transition are intriguing; its possible relationship to tectonic and oceanographic events is discussed in greater depth elsewhere (Zimmerman, this volume).

Most encouraging is the fact that when relatively undisturbed samples are recovered, their physical properties provide much more than textural information. As indicated by the Leg 68 results, physical property data can provide important insight into the paleoceanographic and tectonic factors ultimately responsible for the deposition of deep sea sediment. To pursue in greater depth the possibilities for extracting paleoceanographic information from HPC samples, more detailed studies are currently underway. In particular, consolidation experiments are being carried out on the Leg 68 samples. These studies together with detailed scanning electron microscope analyses of the HPC material, should provide valuable information on the depositional history of deep sea sediments.

The Hydraulic Piston Corer has provided some of the highest-quality samples yet available for the study of 
deep sea physical properties. If the full potential of the HPC as a physical property sampling tool is to be realized, however, some modifications must be made in sampling procedures. Ideally, cores retrieved from the HPC should be kept vertical, sealed, stored refrigerated in seawater, and decoupled from the ship's vibrations until they can be sampled in the carefully controlled conditions of a shore-based lab. Of course, it is totally impractical to expect this procedure to be carried out for every hole, but if a few carefully chosen holes were treated in this manner, the physical property results should be far superior to any obtained thus far and well worth the extra effort.

\section{REFERENCES}

Baas Becking, L. G. M., and Moore, D., 1959. Density distribution in sediments. J. Sediment. Petrol. 29(No. 1):47-55.

Bennett, R. H., and Keller, G. H., 1973. Physical properties evaluations. In van Andel, Tj. H., Heath, G. R., et al., Init. Repts. $D S D P, 16$ : Washington (U.S. Govt. Printing Office), 521-528.

Demars, K. R., and Nacci, V. A., 1978. Significance of Deep Sea Drilling Project sediment physical property data. Mar. Geotechnol., 3 (No. 2):151-170.

Demars, K. R., Nacci, V. A., and Kelley, W. E., 1979. Engineering and other physical property data, Leg 43. In Tucholke, B. E., Vogt, P. R., et al., Init. Repts. DSDP, 43: Washington (U.S. Govt. Printing Office), 757-768.

Hamilton, E. L., 1964. Consolidation characteristics and related properties of sediments from Experimental Mohole (Guadalupe Site). J. Geophys. Res., 69:4257-4269.

1965 . Sound speed and related physical properties of sediments from Experimental Mohole (Guadalupe Site). Geophysics, 30(No. 2):257-261.

1976. Variations of density and porosity with depth in deepsea sediments. J. Sediment. Petrol., 46(No. 2):280-300.

1979. Sound velocity gradients in marine sediments, $J$. Acoust. Soc. Am., 65(No. 4):909-922.

Johnson, T. C., Hamilton, E. L., and Berger, W. H., 1977. Physical properties of calcareous ooze; control by dissolution at depth. Mar. Geol., 24:259-277.

Joides Journal, 1979. Cover photo, Vol. 5 (No. 2).

Keller, G. H., and Bennett, R. H., 1970. Variations in the mass physical properties of selected submarine sediments. Mar. Geol., 9: 215-223.
1973. Sediment mass physical properties-Panama Basin and Northeastern Equatorial Pacific. In van Andel, Tj. H., Heath, G. R., et al., Init. Repts. DSDP, 16: Washington (U.S. Govt. Printing Office), 499-512.

Lambe, T. W., and Whitman, R. V., 1969. Soil Mechanics: New York (John Wiley).

Lee, H. J., 1973. Measurements and estimates of engineering and other physical properties: Leg 19. In Creager, J. S., Scholl, D. W., et al., Init. Repts. DSDP, 19: Washington (U.S. Govt. Printing Office), 701-720.

1979. Offshore soil sampling and geothechnical parameter determination. Proceedings of the Offshore Technology Conference, \# OTC 3524, Houston, Texas.

Mayer, L. A., 1979. Deep sea carbonate: Acoustic, physical, and stratigraphic properties. J. Sediment. Petrol., 49(No. 3):0819-0836.

Nooran Y. I., and Gyinski, S. F., 1970. Engineering properties of submarine soils: State of the art review. Proc. Am. Soc. Civ. Eng., Soil Mech. Found. Div., 96:1735-1762.

Prell, W. L., Gardner, J. V., Adelseck, C. G., Blechschmidt, G., Fleet, A. J., Keigwin, L. D., Kent, D., Ledbetter, M. T., Mann, U., Mayer, L., Reidel, W. R., Sancetta, C., Spariosu, D., and Zimmerman, H. B., 1980. Hydraulic piston coring of late Neogene and Quaternary sections in the Caribbean and equatorial Pacific: Preliminary results of Deep Sea Drilling Project Leg 68. Geol. Soc. Amer. Bull., 91:433-444.

Rocker, K., 1974. Physical properties measurements and test procedures of Leg 27. In Veevers, J. J., Heirtzler, J. R., et al., Init. Repts. DSDP, 27: Washington (U.S. Govt. Printing Office), 433-443.

Schlanger, S. O., and Douglas, R. G., 1974. The pelagic ooze-chalklimestone transition and its implications for marine stratigraphy. In Hsü, K. J., and Jenkyns, H. C. (Eds), Pelagic Sediments on Land and under the Sea. Special Publication International Association of Sedimentologists, 1:117-148.

Trabant, P. K., 1978. Synthesis of physical properties data from DSDP Leg 41. In Lancelot, Y., Seibold, E., et al., Init. Repts. DSDP, 41: Washington (U.S. Govt. Printing Office), 1199-1213.

Trabant, P. K., Bryant, W. R., and Bouma, A. H., 1975. Consolidation characteristics of sediments from Leg 31 of the DSDP. In Karig, D. E., Ingle, J. C., Jr., et al., Init. Repts. DSDP, 31: Washington (U.S. Govt. Printing Office), 569-572.

Tucholke, B. E., Edgar, N. T., and Boyce, R. E., 1976. Physical properties of sediments and correlations with acoustic stratigraphy: Leg 35, DSDP. In Hollister, C. D., Craddock, C., et al., Init. Repts. DSDP, 35: Washington (U.S. Govt. Printing Office), 229-250.

Wilson, N. E., 1964. Laboratory vane shear tests and the influence of pore-water stresses. Laboratory Shear Testing of Soils., ASTM Spec. Tech. Publ., 361: 377-389. 


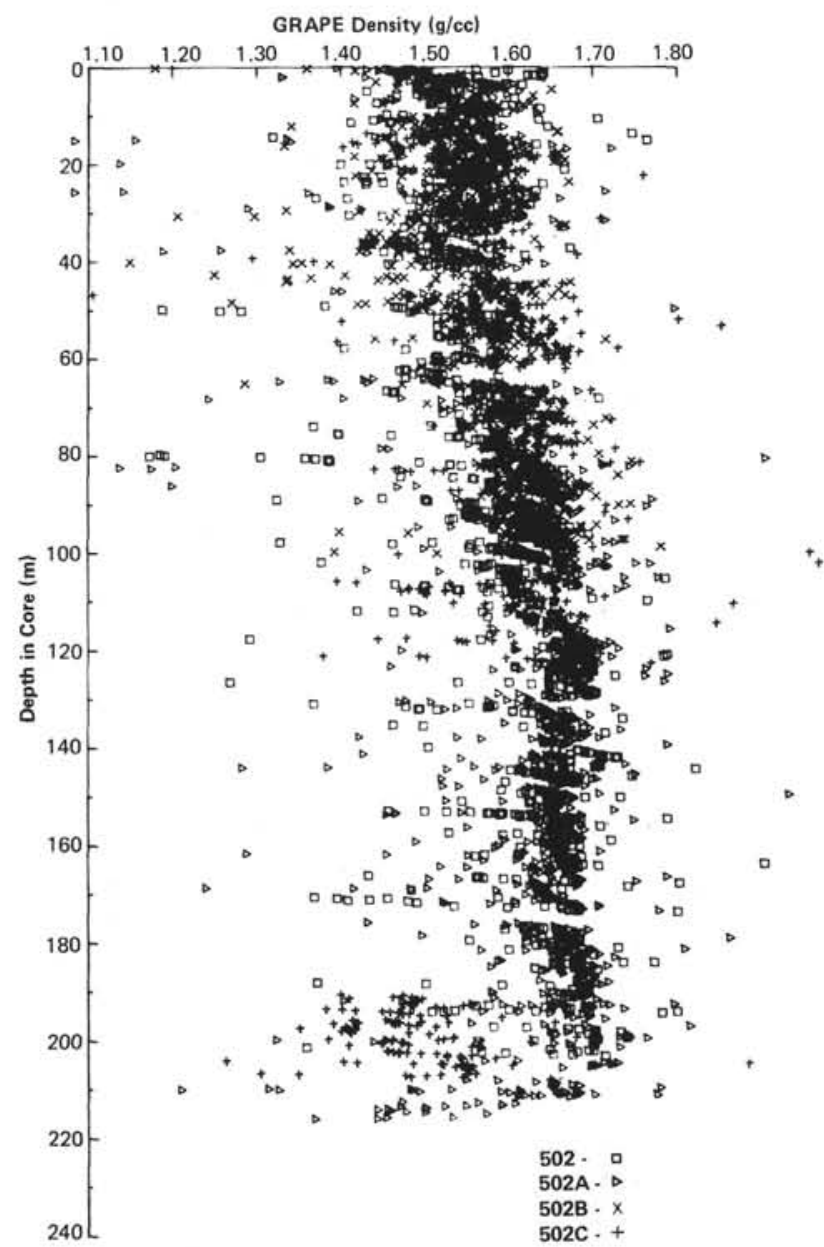

Figure 1. Saturated bulk density (as measured by GRAPE) versus depth in core for Site 502 cores. GRAPE data is displayed at $15-\mathrm{cm}$ intervals.

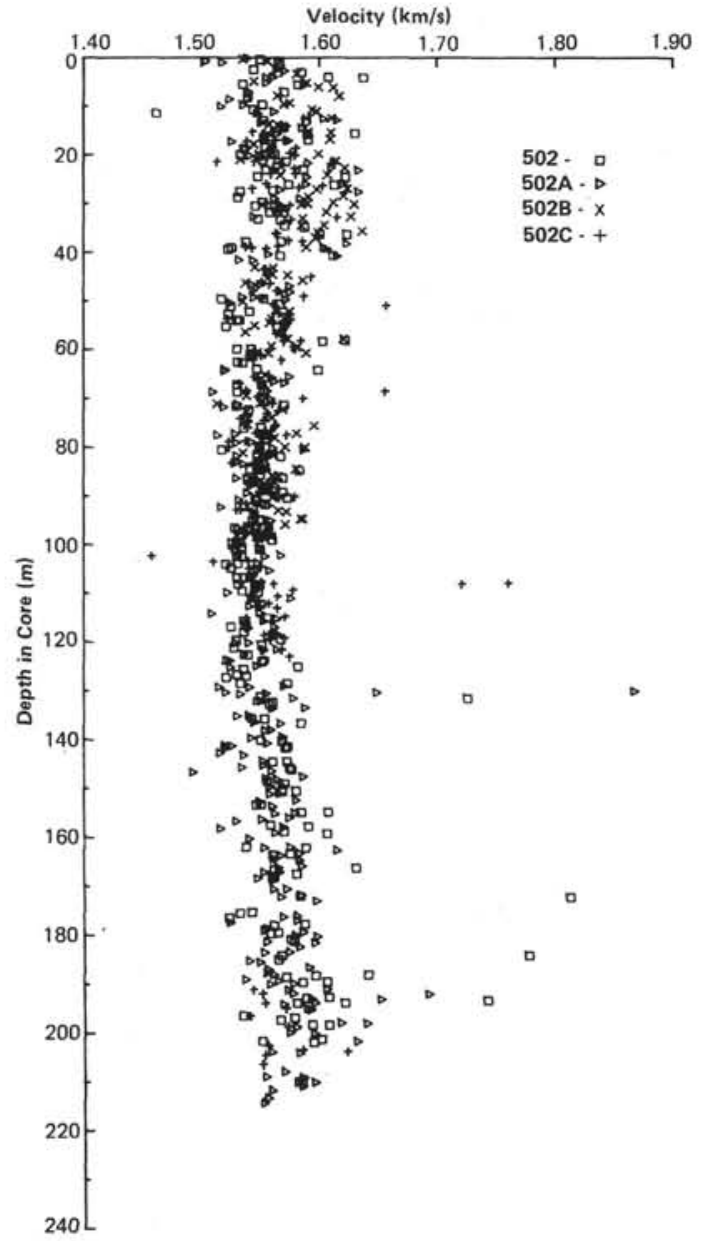

Figure 2. Compressional-sound velocity versus depth in core for Site 502 cores. Includes both through the liner (TTL) and chunk sample (CHK) measurements. 


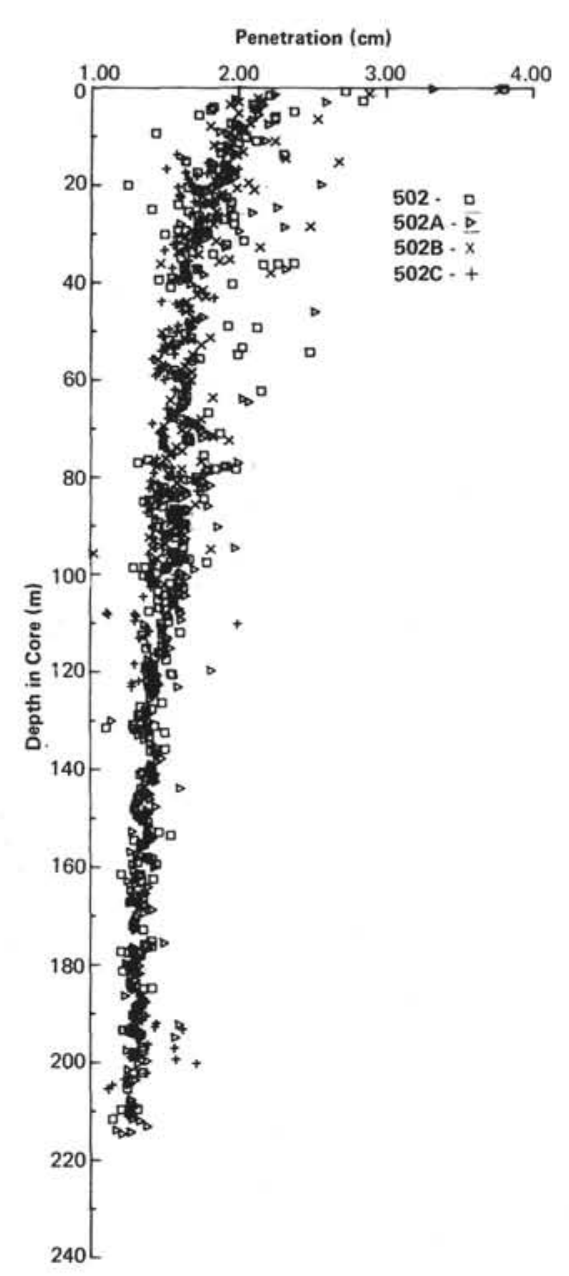

Figure 3. Needle penetration versus depth in core for Site 502 cores.

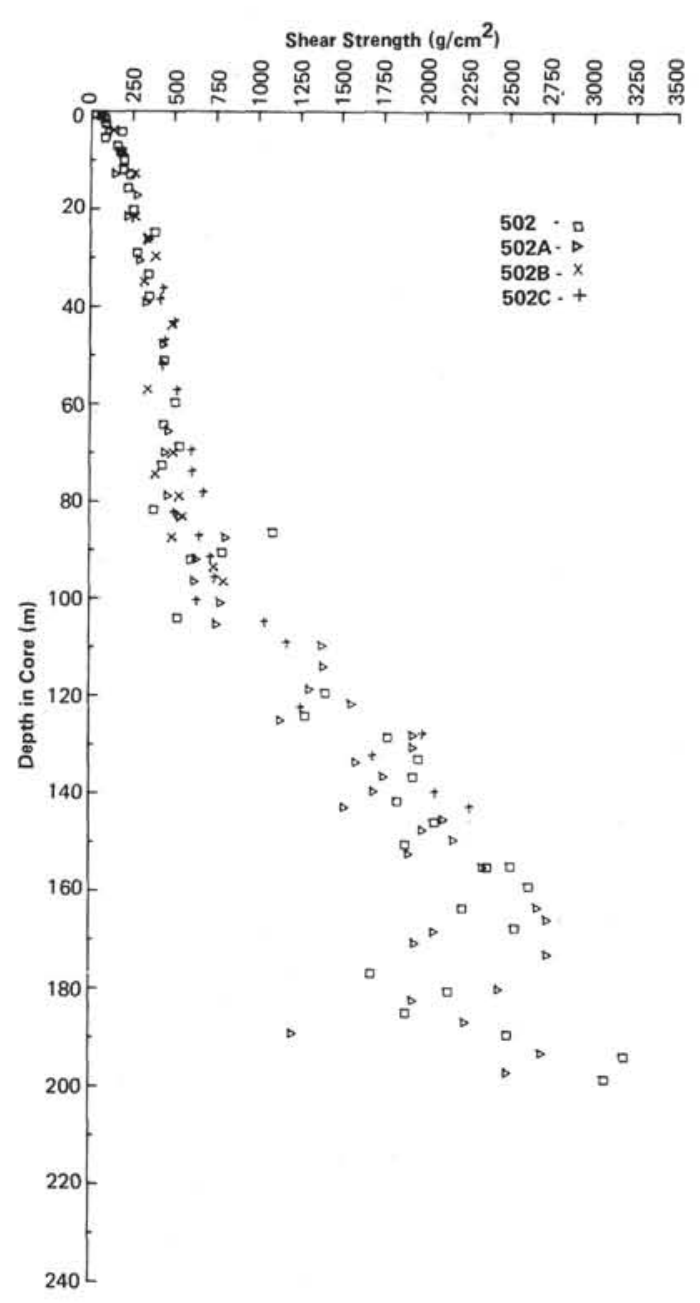

Figure 4. Shear strength versus depth in core for Site 502 cores. Data points from disturbed samples are not included. 


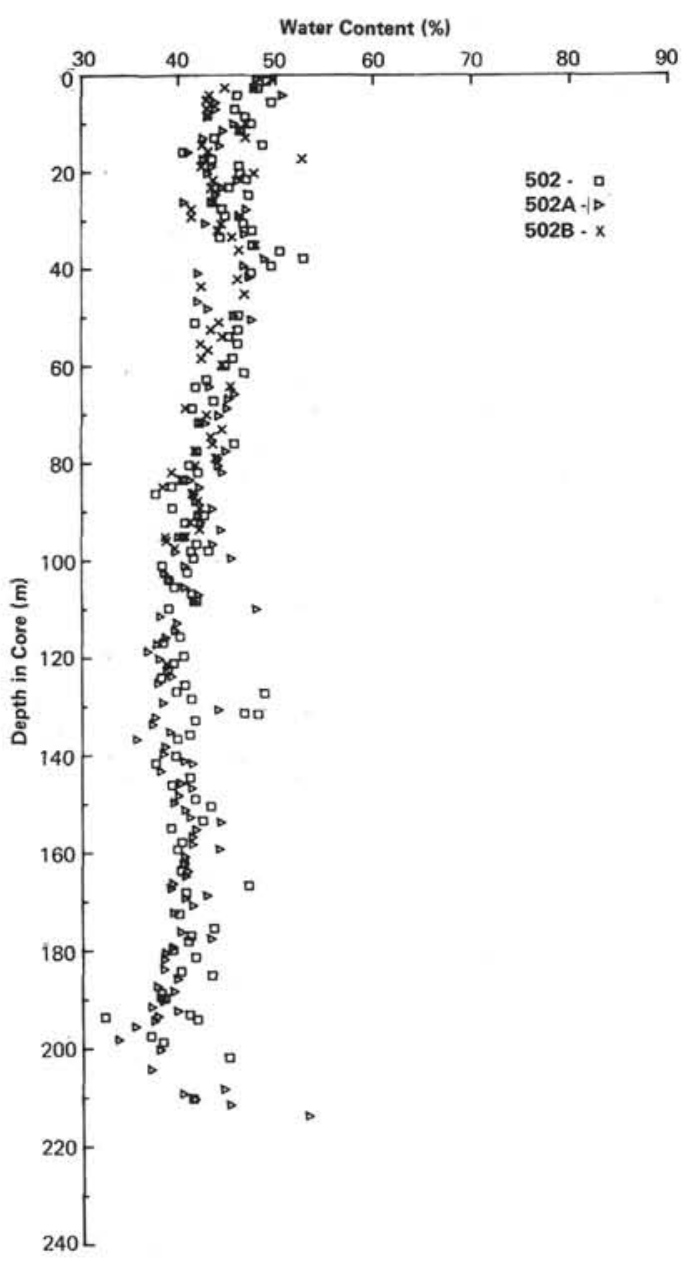

Figure 5. Water content versus depth in core for Site 502 cores. No measurements were made for Hole 502C.
Sat, Bulk Density $(\mathrm{g} / \mathrm{cc})$

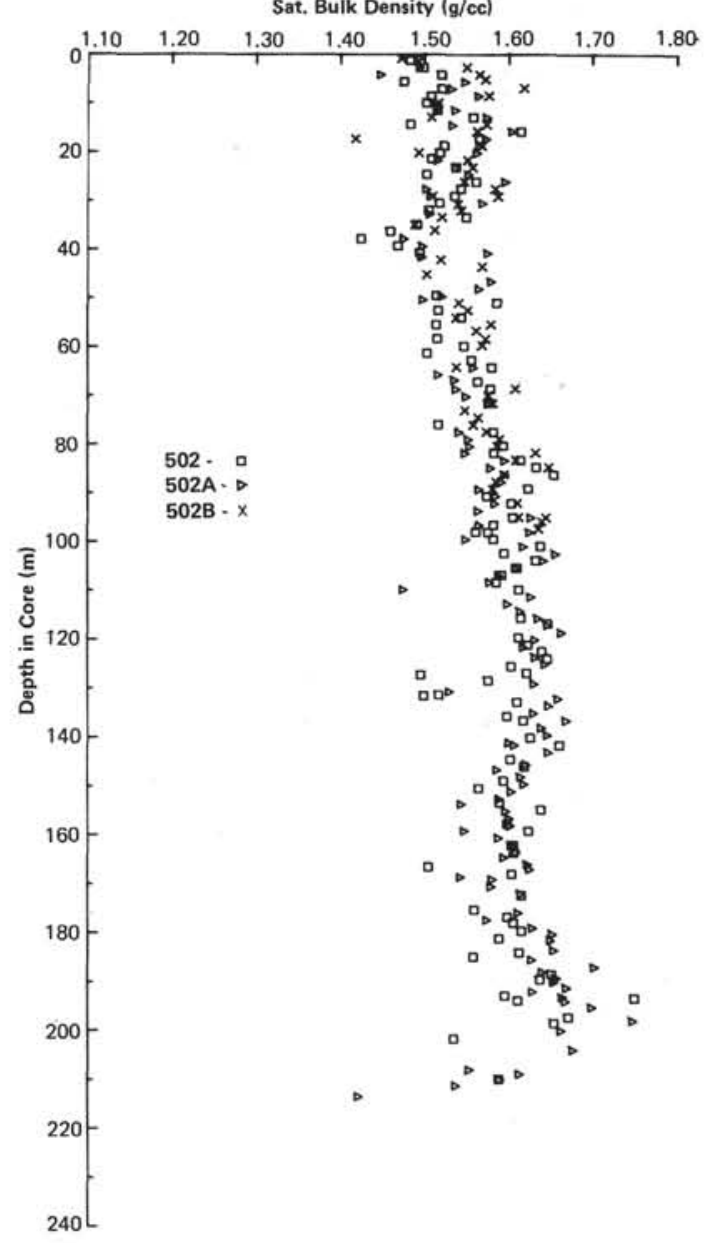

Figure 6 . Saturated bulk density (as measured by gravimetric means) versus depth in core for Site 502 cores. No measurements were made for Hole 502C. 


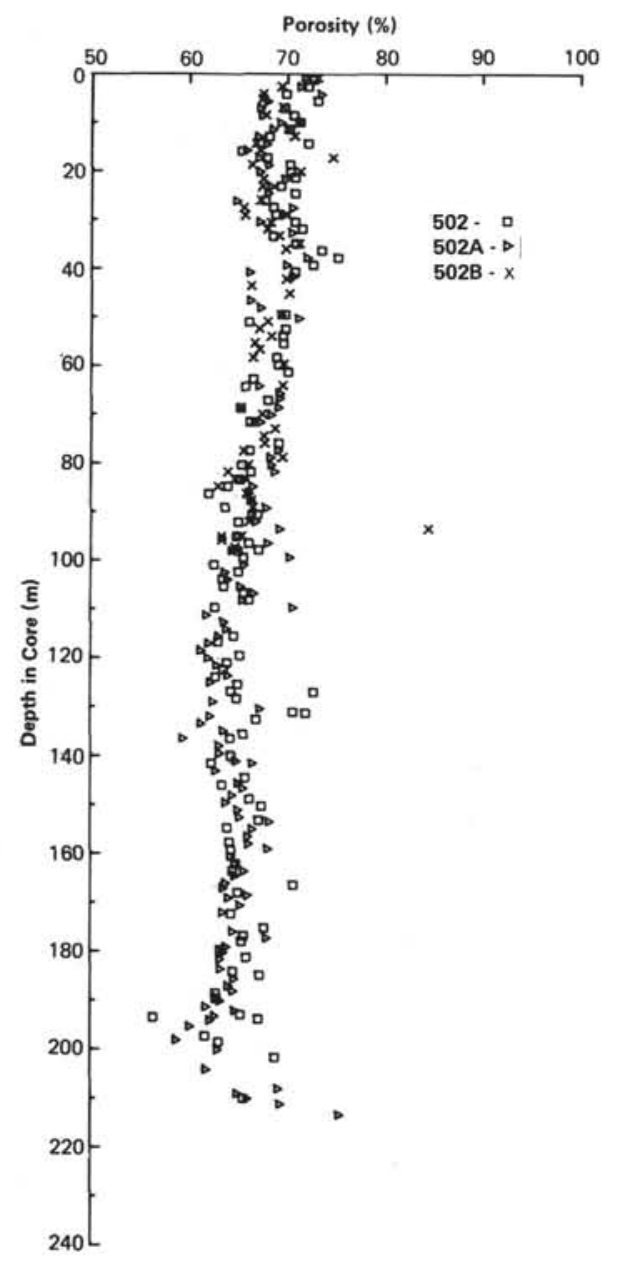

Figure 7. Porosity versus depth in core for Site 502 cores. No measurements were made for Hole 502C.

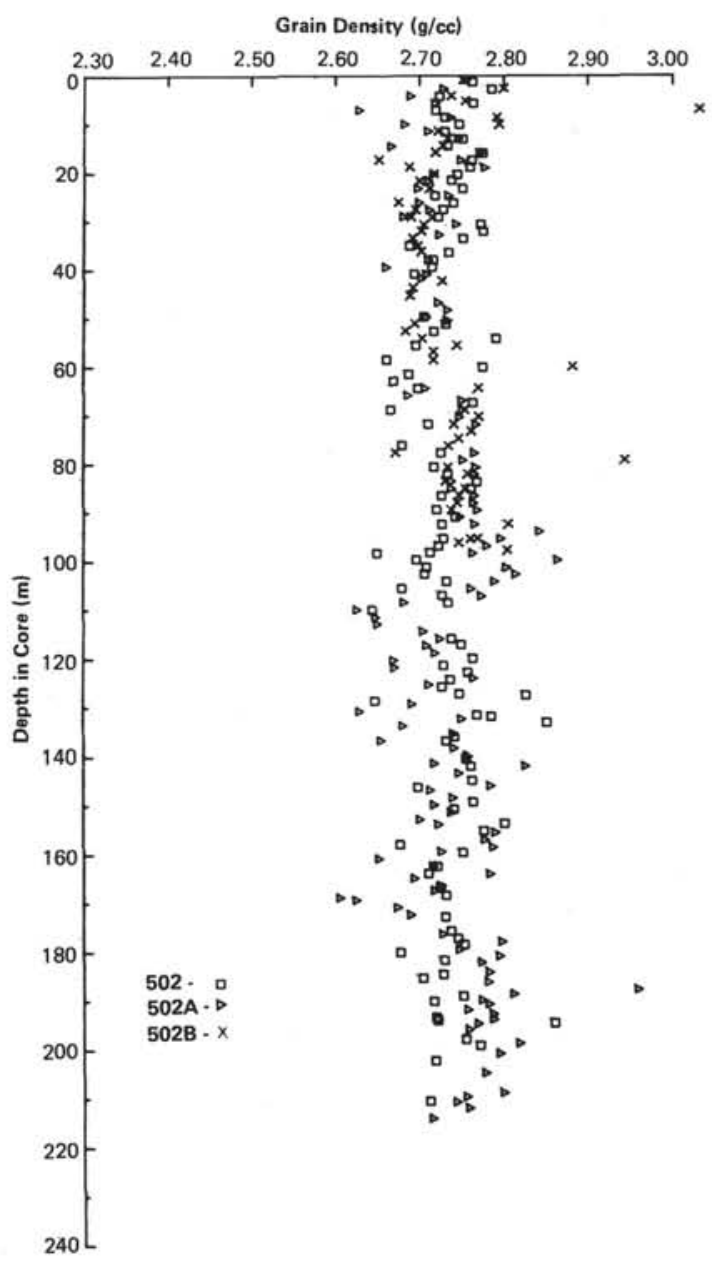

Figure 8. Grain density versus depth in core for Site 502 cores. No measurements were made for Hole 502C. 


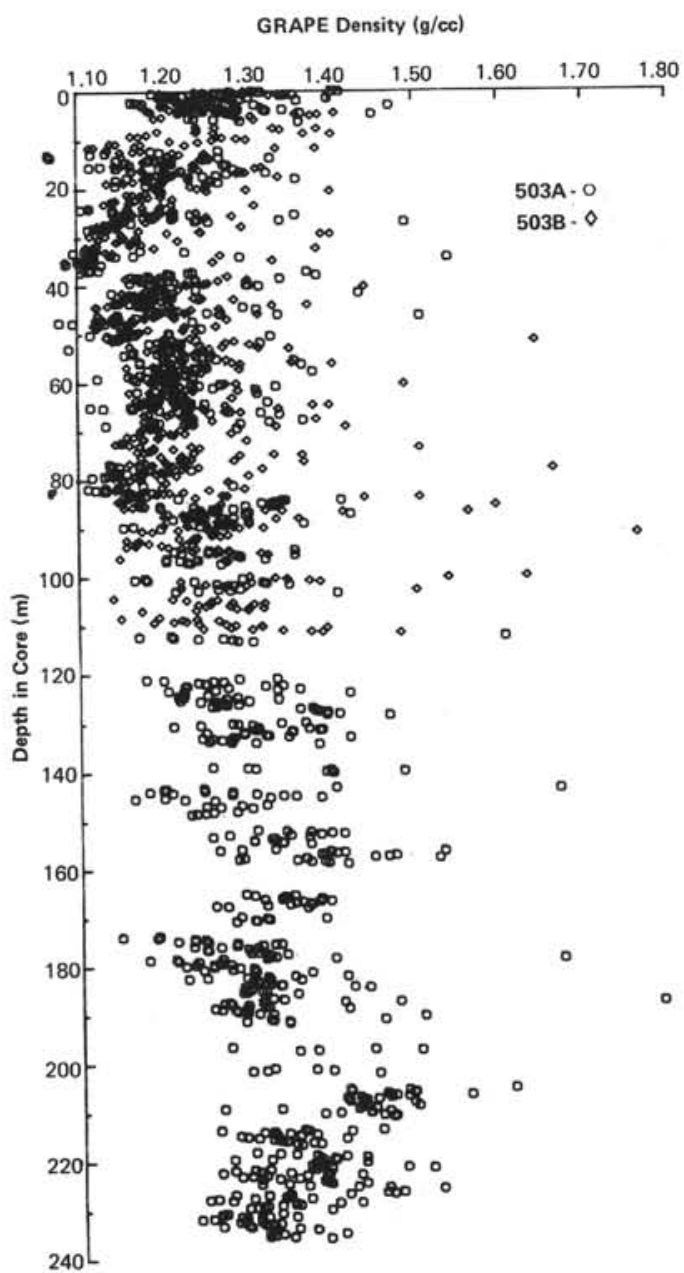

Figure 9 . Saturated bulk density (as measured by GRAPE) versus depth in core for Site 503 cores. GRAPE data is displayed at $15-\mathrm{cm}$ intervals.

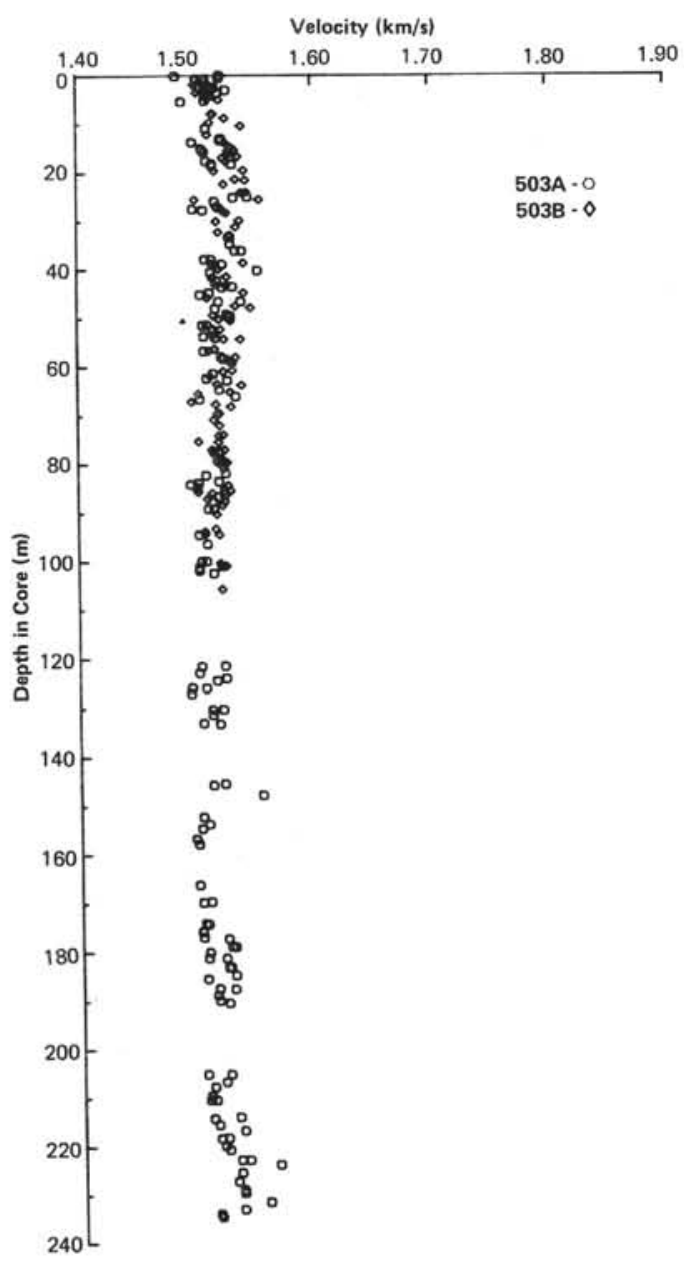

Figure 10. Compressional-sound velocity versus depth in core for Site 503 cores. Includes both through the liner (TTL) and chunk sample (CHK) measurements. 


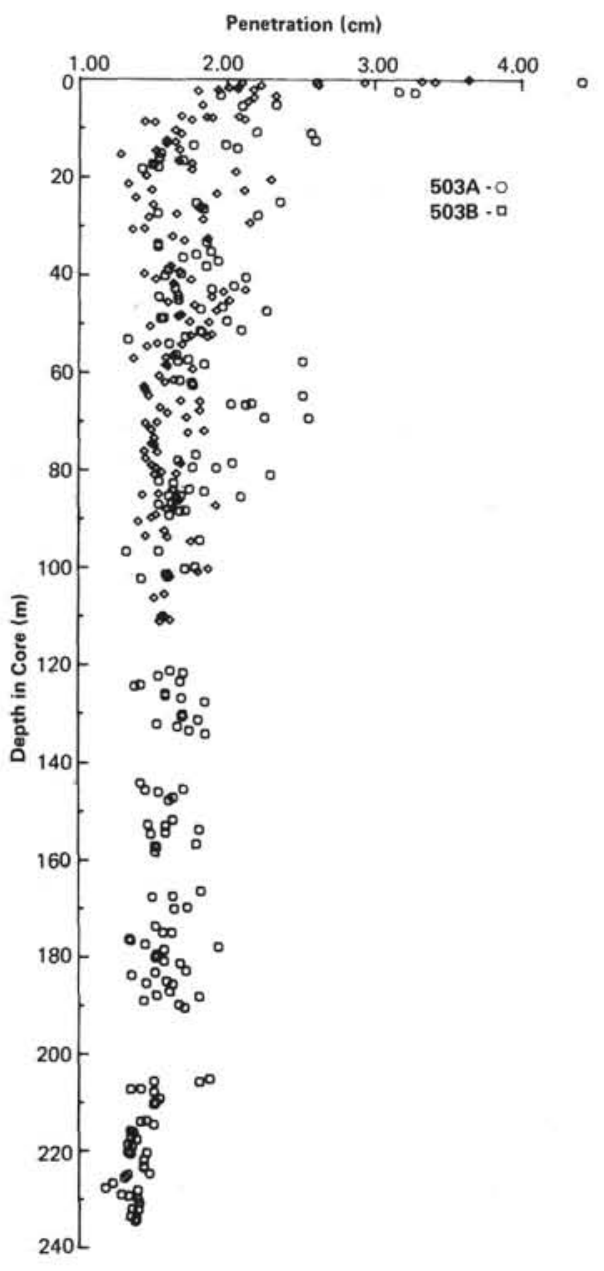

Figure 11. Needle penetration versus depth in core for Site 503 cores.

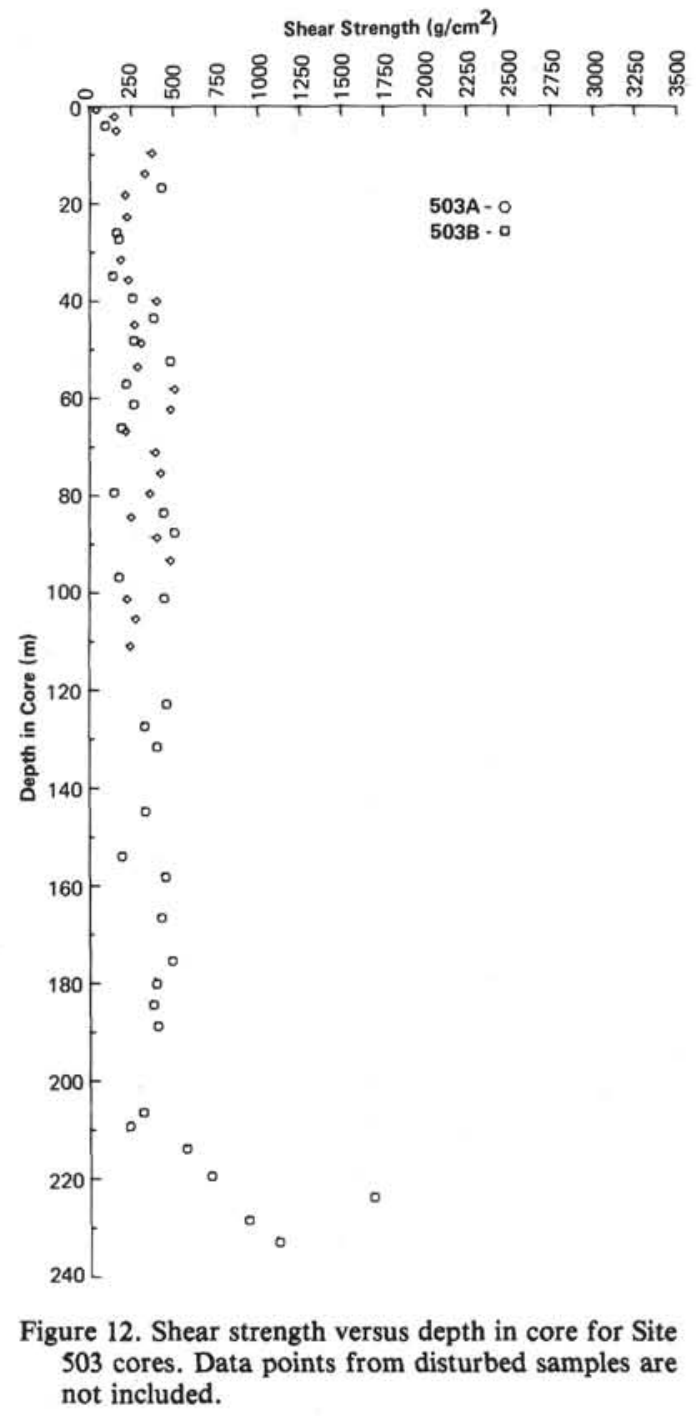




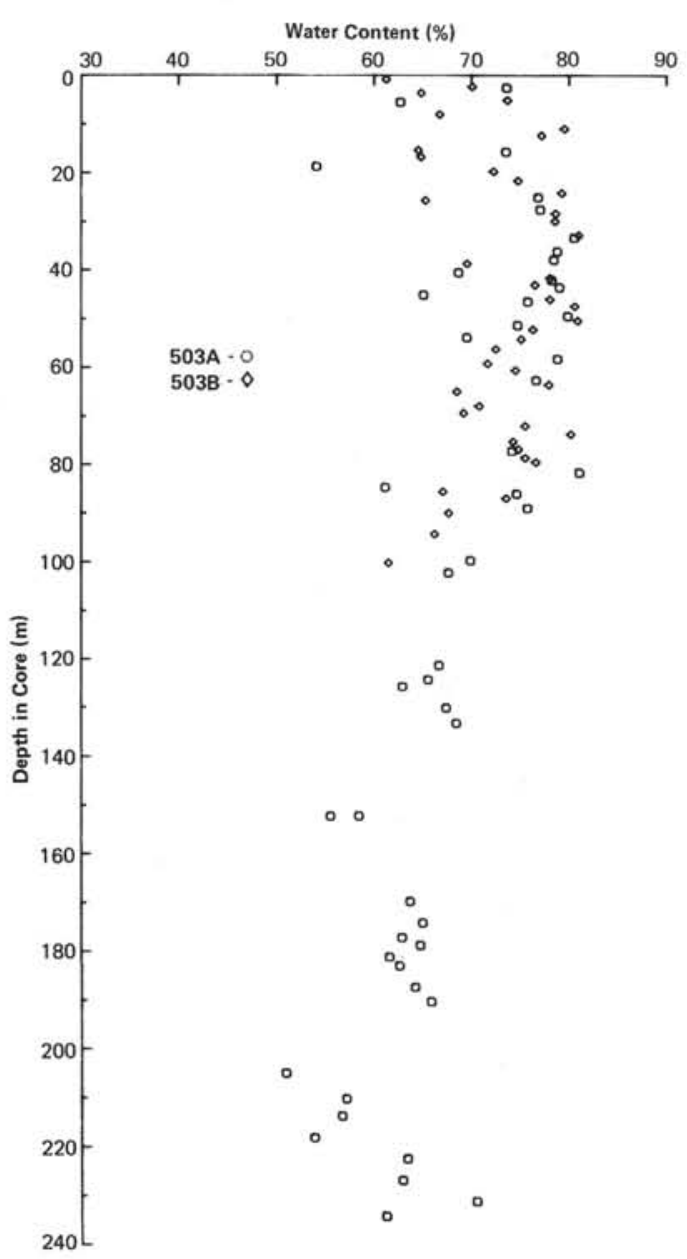

Figure 13. Water content versus depth in core for Site 503 cores.

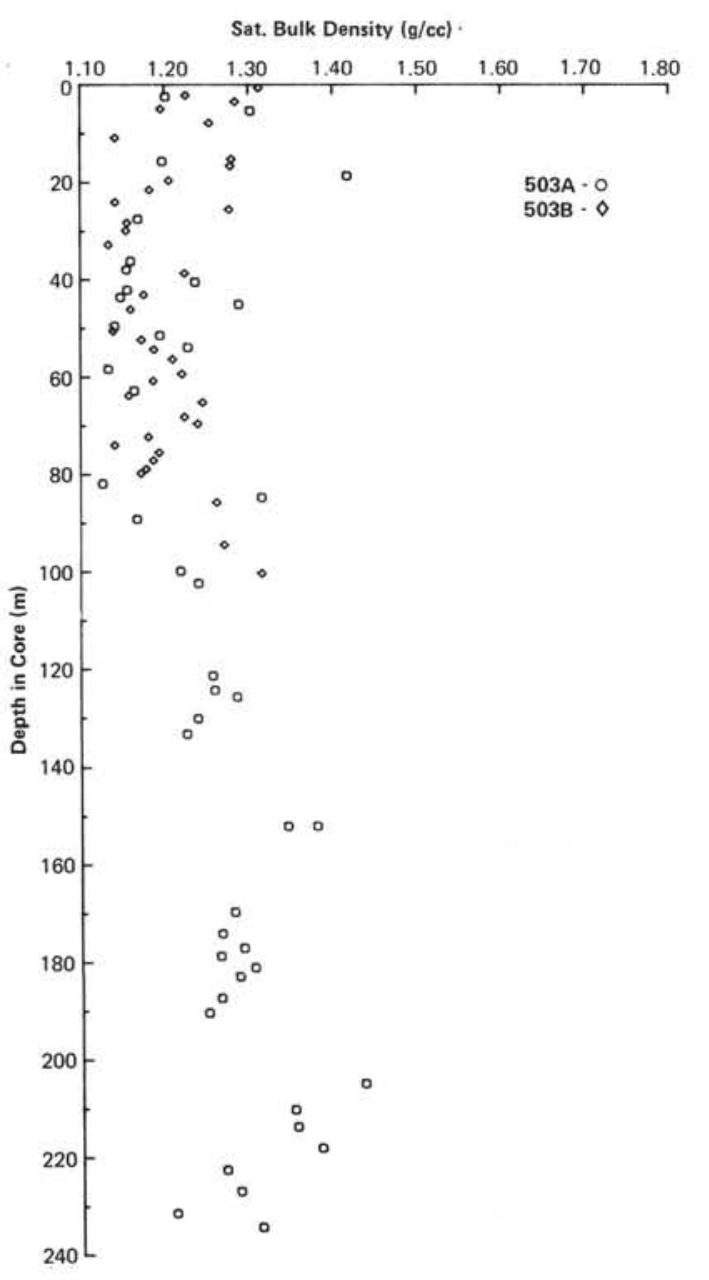

Figure 14. Saturated bulk density (as measured by gravimetric means) versus depth in core for Site 503 cores. 


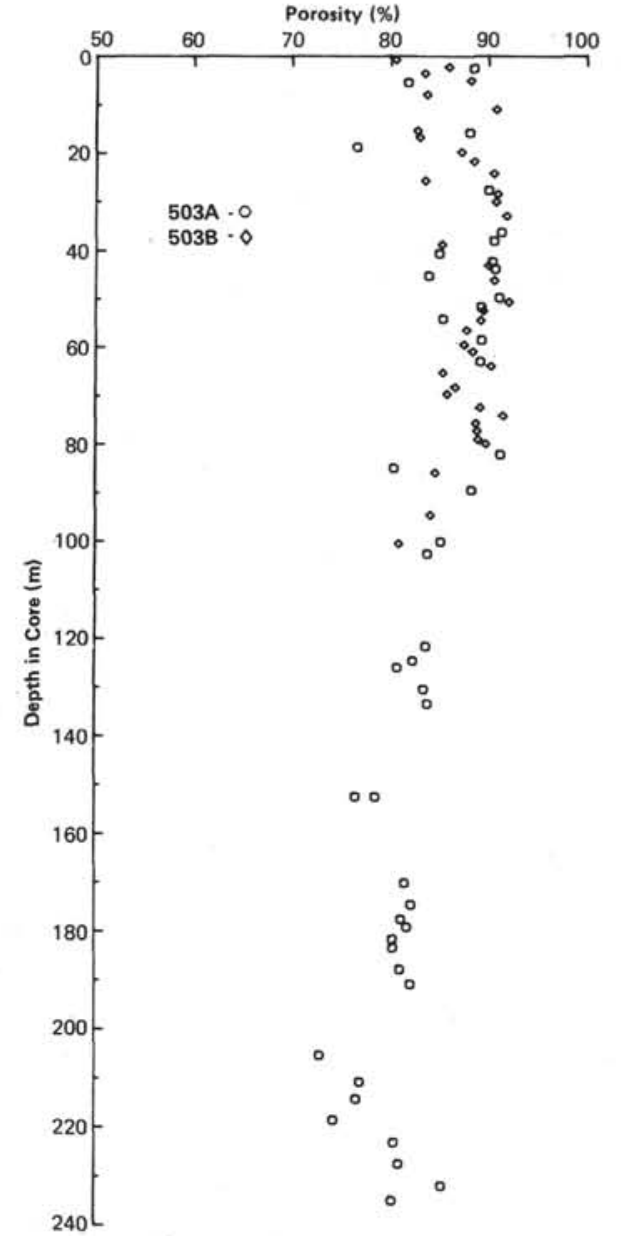

Figure 15. Porosity versus depth in core for Site 503 cores.

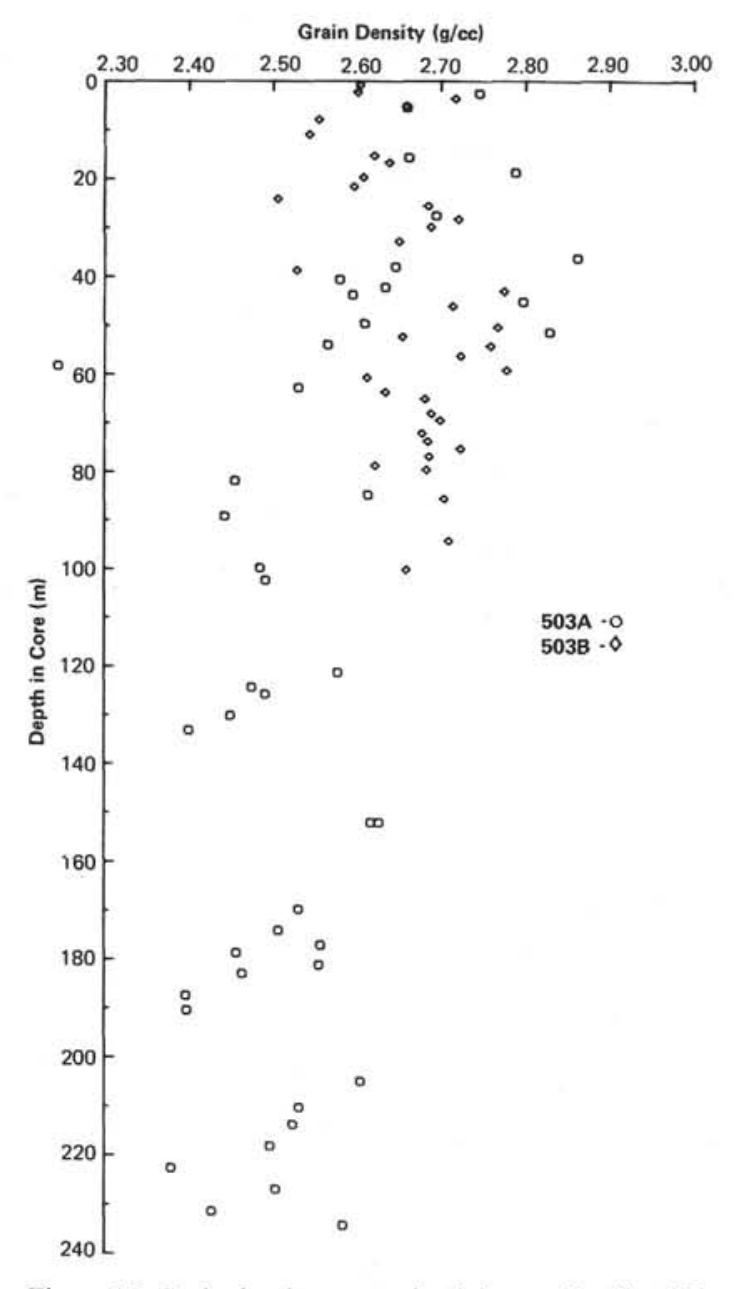

Figure 16. Grain density versus depth in core for Site 503

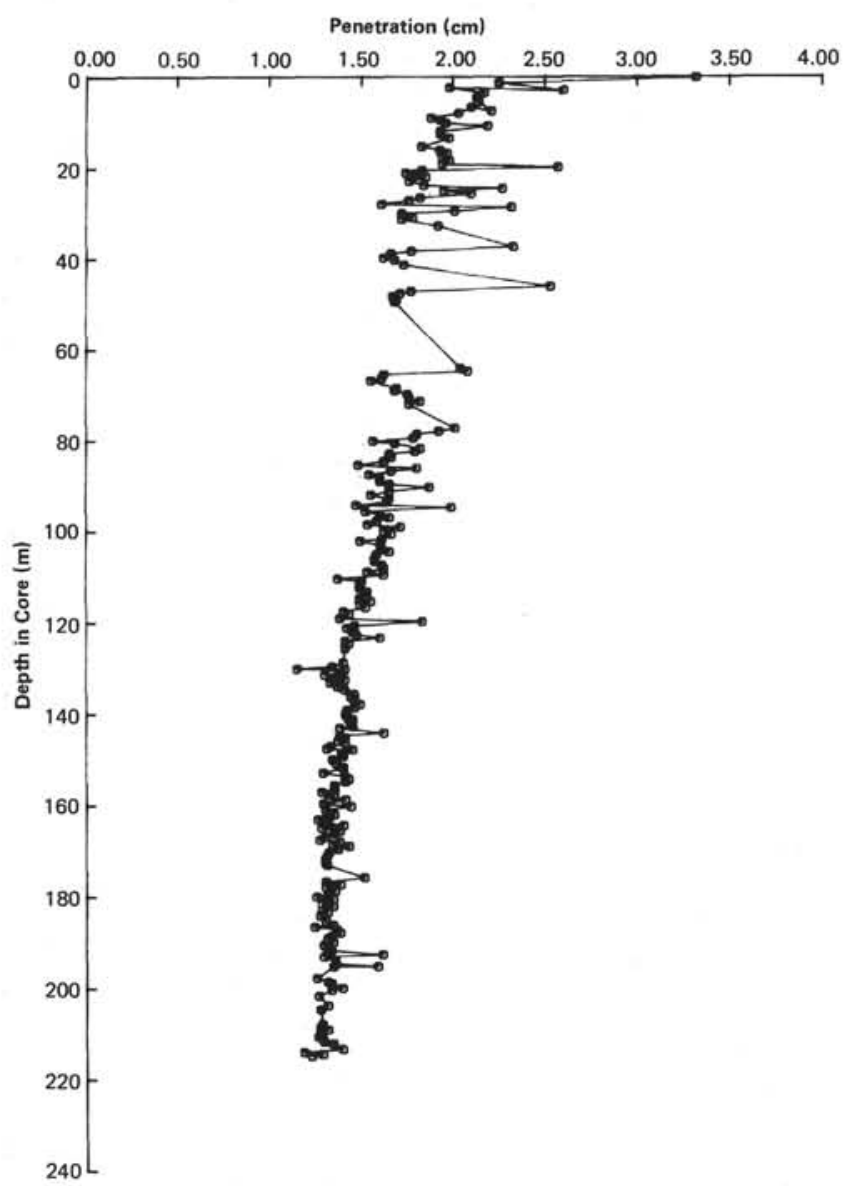

Figure 17. Penetration versus depth for Hole 502A. 


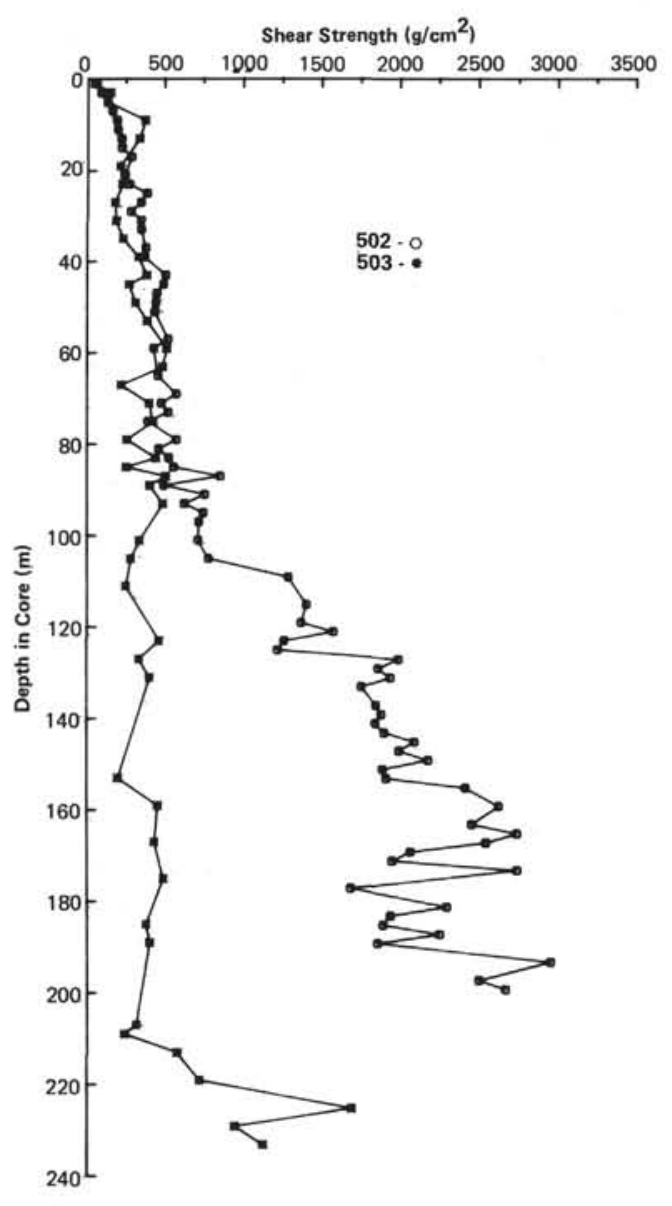

Figure 18. Smoothed shear strength versus depth for Leg 68 cores. Disturbed points have been removed.

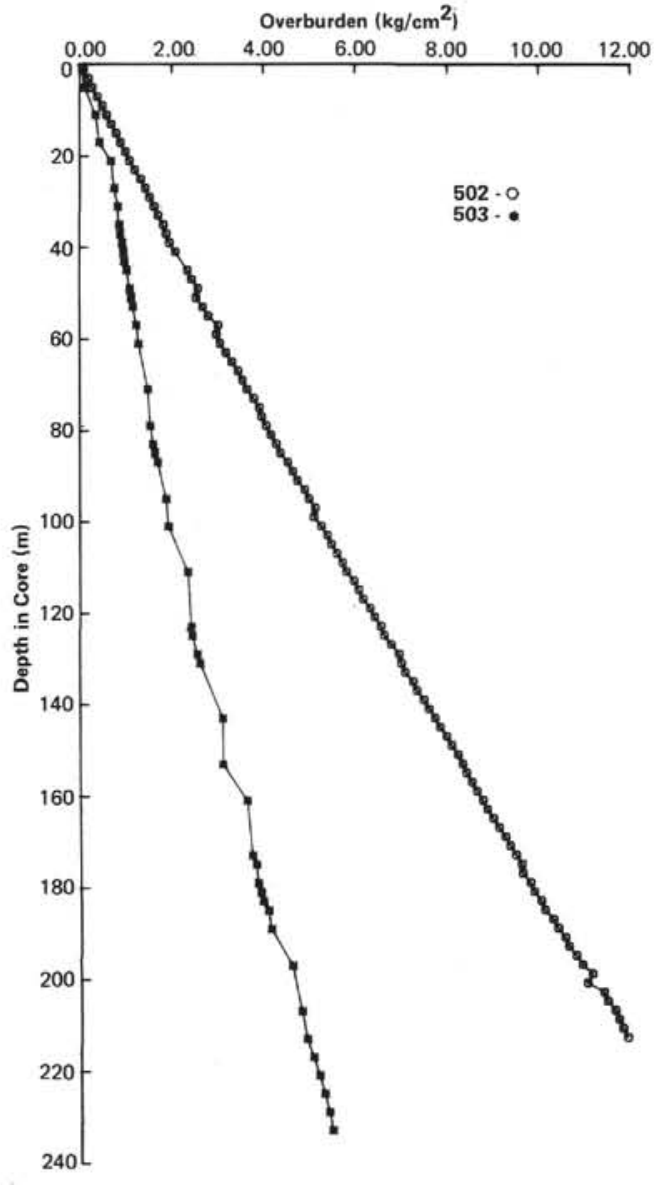

Figure 19. Overburden versus depth for Leg 68 cores. Calculated from saturated bulk density measured by gravimetric techniques.

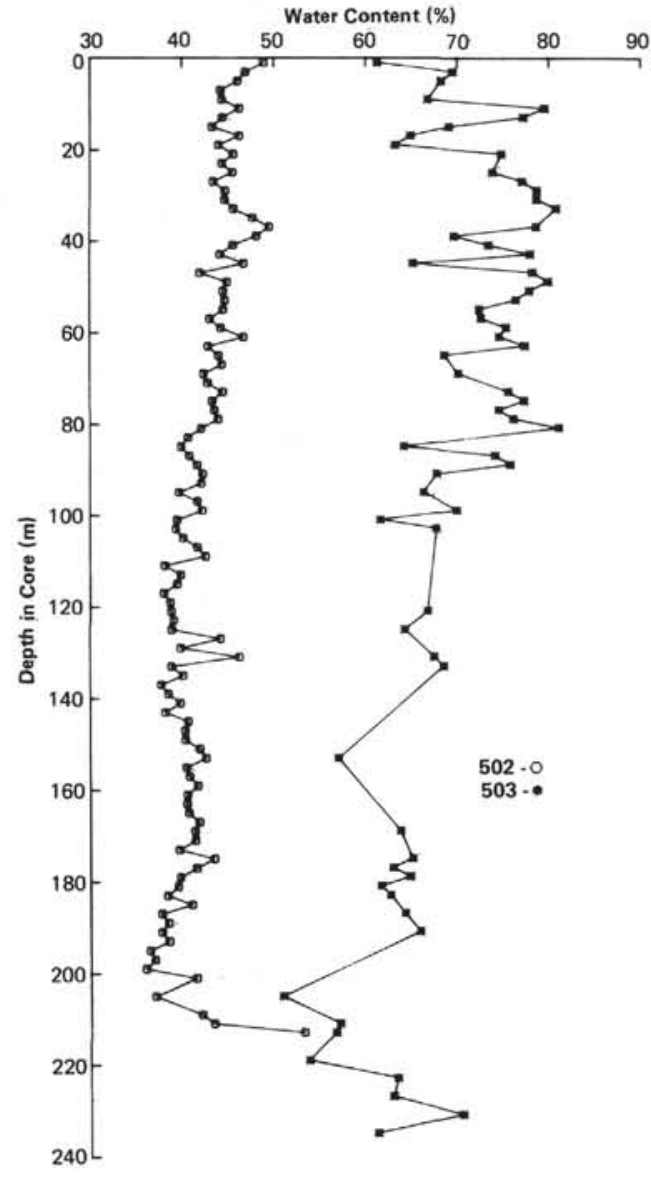

Figure 20. Smoothed water content versus depth for Leg 68 cores. 


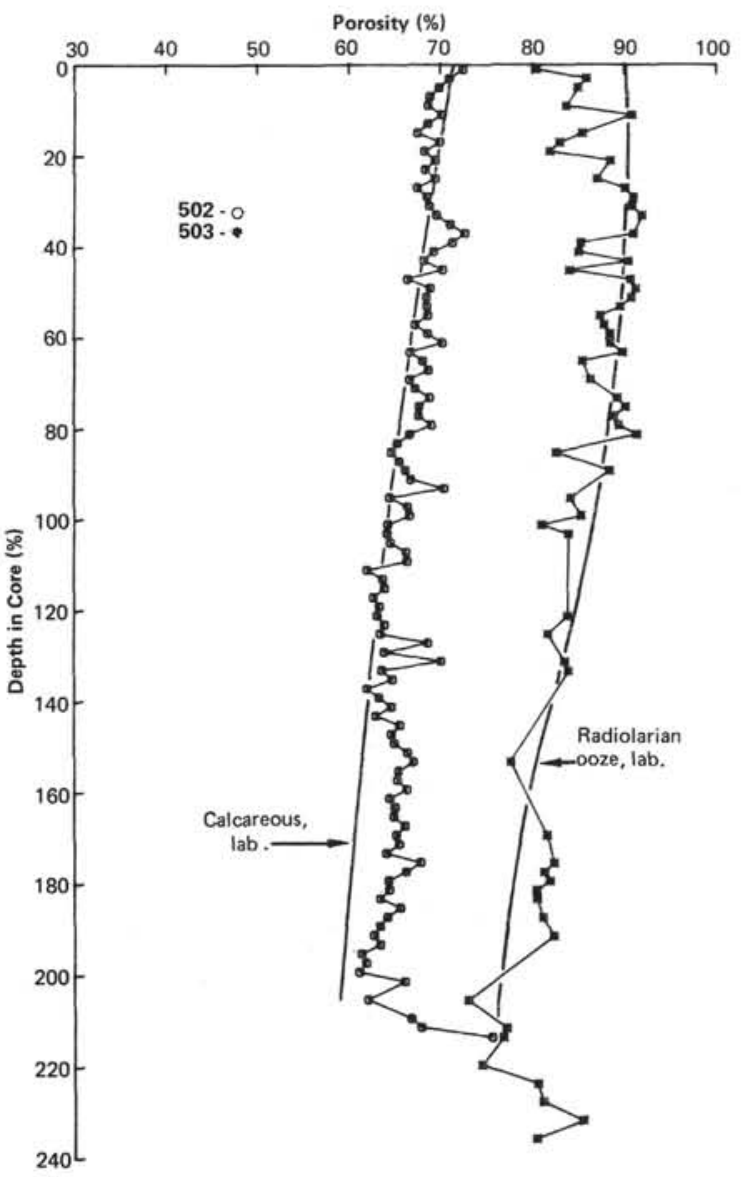

Figure 21. Smoothed porosity versus depth for Leg 68 cores. Smooth lines are generalized laboratory curves for calcareous sediment (superimposed on 502) and radiolarian ooze (superimposed on 503) from Hamilton, 1976.

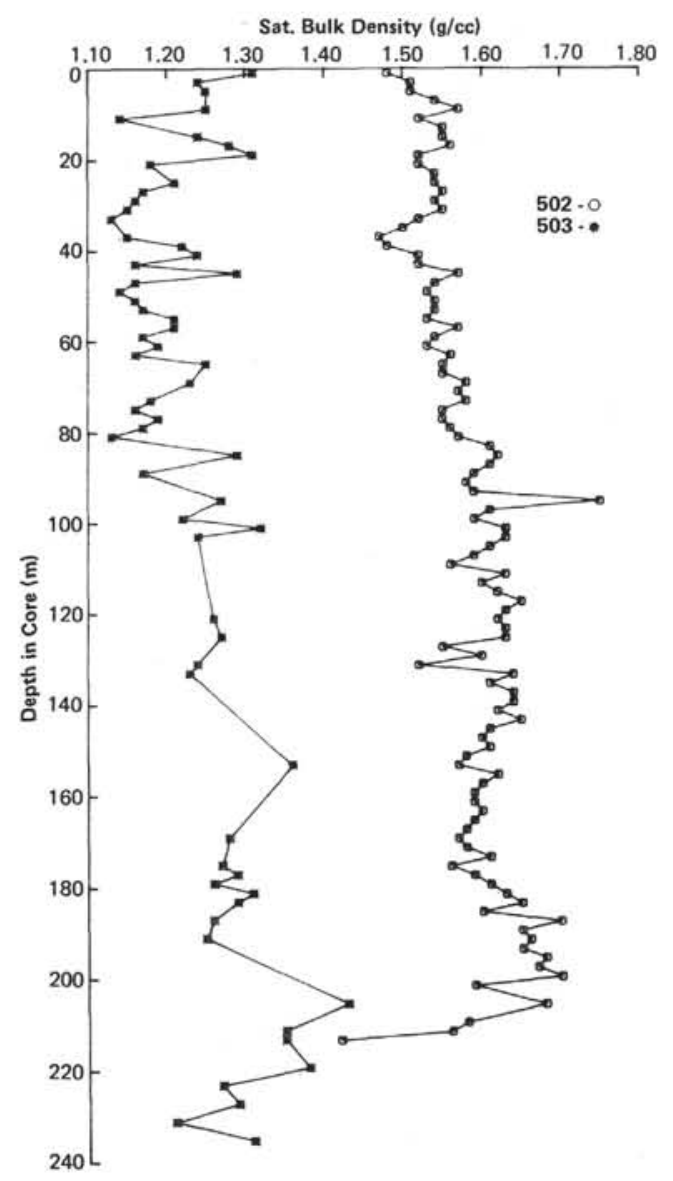

Figure 22. Smoothed saturated bulk density versus depth for Leg 68 cores.

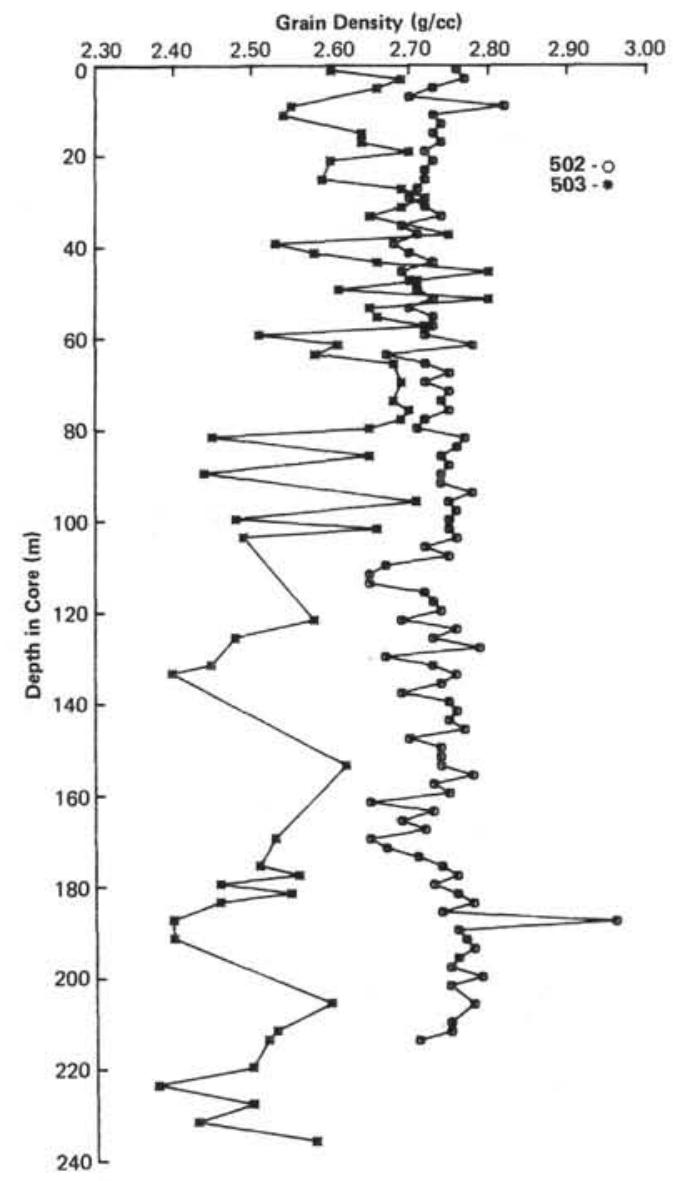

Figure 23. Smoothed grain density versus depth for Leg 68 cores. 


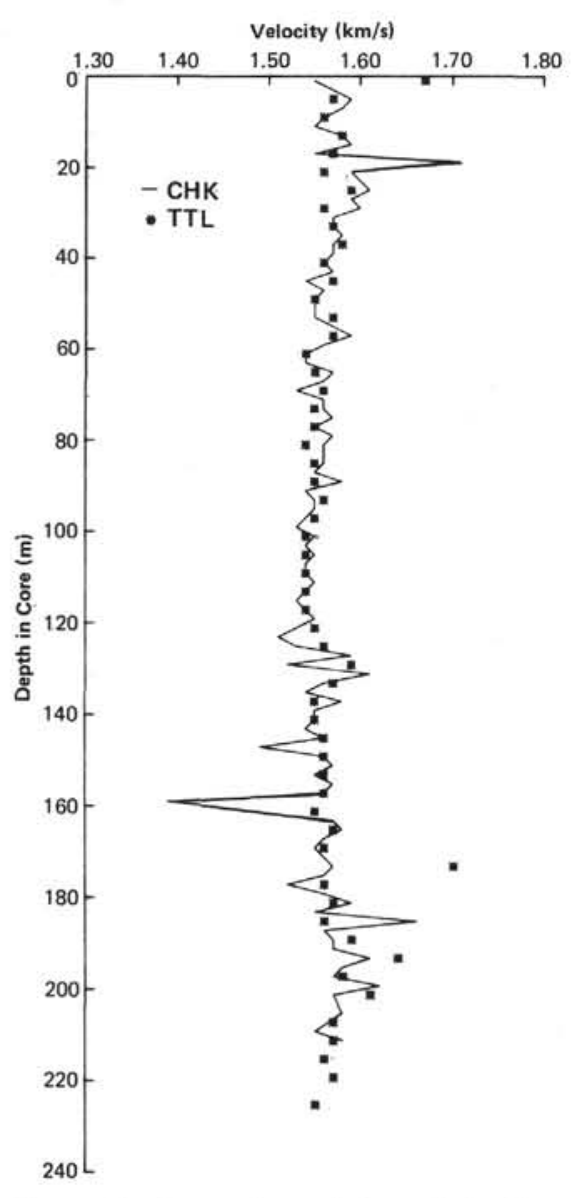

Figure 24. Comparison of through the liner (TTL) velocity measurement with chunk sample (CHK) measurement for Hole 502 cores.

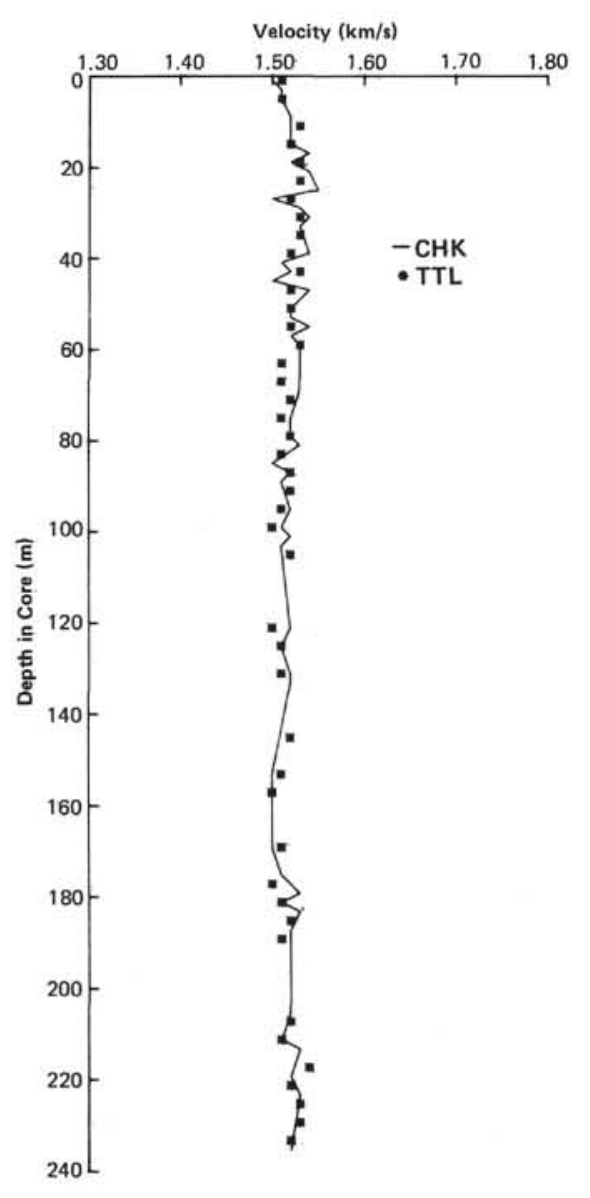

Figure 25. Comparison of through the liner (TTL) velocity measurement with chunk sample (CHK) measurement for Hole 503 cores.

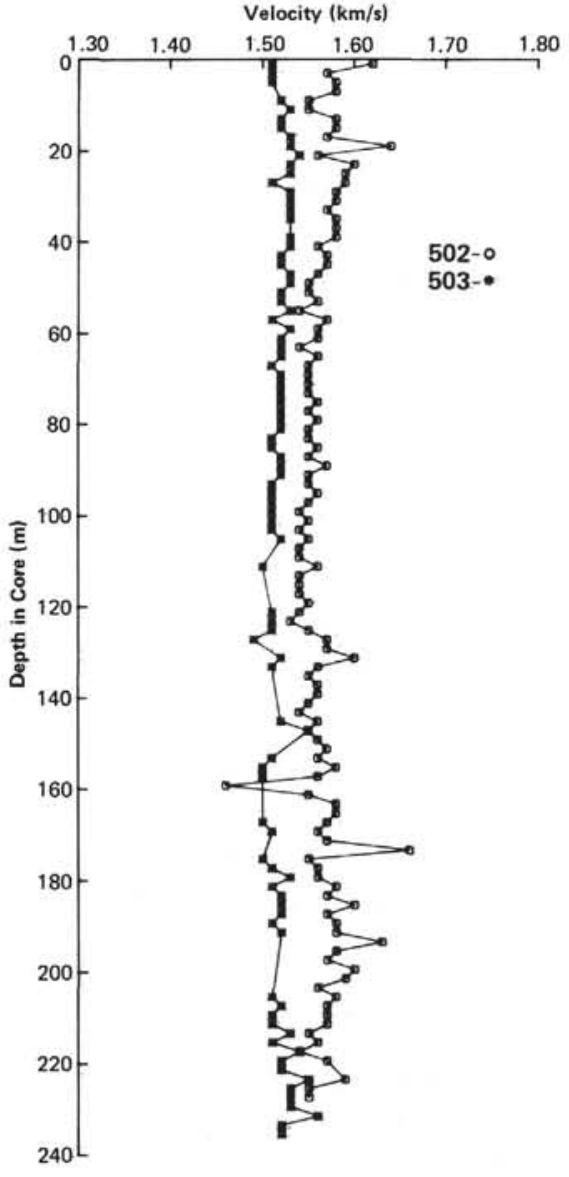

Figure 26. Smoothed sonic velocity versus depth for Leg 68 cores. 